\title{
Institutional Complementarities and Gender Diversity on Boards: A Configurational Approach
}

\author{
Michela Iannotta*, Mauro Gatti, and Morten Huse
}

\begin{abstract}
Manuscript Type: Empirical

Research Question/Issue: To address the lack of a complementarities-based approach in studies of board diversity, this paper seeks to understand whether and how certain country-level factors are causally and jointly related to women on boards and the nature of their complementarities (are they synergic or substitutes?). Moreover, we intend to learn more about the adoption/diffusion of board gender quotas, by taking into account their role in the existing national configurations (whether they are necessary and/or sufficient conditions).

Research Findings/Insights: Using fs/QCA, our findings reveal a particular configuration of country-level conditions that supports the existence of a joint causal relation between given institutional arrangements. Furthermore, we find that board gender quota legislation is not a sufficient condition on its own to achieve a higher number of women on boards. Such evidence suggests that its diffusion across countries could be the result of institutional isomorphism or social legitimacy more than to rational reasons.

Theoretical/Academic Implications: For scholars, our paper refines and expands insights from the extant comparative corporate governance literature. By finding support for the "bundled" or jointly causal nature of given institutional factors, we open a window for further research that investigates board-level phenomena in a complementarities-based perspective.

Practitioner/Policy Implications: For policy makers, this study provides some insights that could better drive their choice about which mix of policies is necessary to improve female representation on boards, and especially in which institutional areas they should be implemented. It is particularly relevant, because once gender quotas are endorsed at board level, they could have ambiguous effects on firm performance and corporate governance.
\end{abstract}

Keywords: Corporate Governance, Configurational Approach, Qualitative Comparative Analysis, Women on Boards

\section{INTRODUCTION}

$\mathbf{T}$ here is a vigorous tradition in economic research underlining the influence of institutional environments on a wide range of corporate governance phenomena. Notable examples concern studies of business behaviors and performances (e.g., Ntim \& Soobaroyen, 2013; Zattoni, Pedersen, \& Kumar, 2009), corporate governance legitimacy (e.g., Aguilera \& Jackson, 2003; Judge, Douglas, \& Kutan, 2008), and corporate governance practices (e.g., Aguilera \& Cuervo-Cazurra, 2004; Denis \& McConnell, 2003), such as the adoption/diffusion of international accounting standards or codes of good governance (Alon, 2013; Judge, Li, \& Pinsker, 2010; Zattoni \& Cuomo, 2008). Furthermore, a comparative and country-level literature has explored the effects of institutional antecedents on the composition of corporate boards of directors, with particular regard to gender diversity issues (Adams \& Kirchmaier, 2013; De Anca, 2008; Grosvold, 2011;

Q1 *Address for correspondence: Michela Iannotta, Sapienza University of Rome, Via del Castro Laurenziano 9, 00161 Rome, Italy. E-mail: michela.iannotta@uniroma1.it
Grosvold \& Brammer, 2011; Terjesen \& Singh, 2008). In detail, legal, cultural, and occupational environments have been found to play the most relevant role for the prevalence of women on boards (Adams \& Kirchmaier, 2013; Grosvold \& Brammer, 2011) and, interestingly, a close interdependence between them has appeared in a parallel stream of research (e.g., Esping-Andersen, 1990; Mandel \& Semyonov, 2006; Misra \& Moller, 2005; Orloff, 1993, 1996). Alongside, institutional arguments have spread in the literature about the adoption of gender quota legislation for boards of directors. For instance, Terjesen, Aguilera, and Lorenz (2014) propose that it is highly coherent with the presence of certain institutional factors, while Grosvold and Brammer (2011) support its compensatory role which likely makes up for the deficiencies of others institutions.

This state of the art suggests that gender diversity on corporate boards may be the outcome of multiple complementary institutional domains, as regulatory policies, welfare states, labor, and cultural institutions are not just independent from each other but they appear to be closely interrelated. However, this literature presents two main limitations. First, prior empirical evidence suggests that a relationship between these 
institutional domains exists, but a lack of holistic perspective has limited our knowledge of whether, how, and which country-level factors in each institutional domain are in conjunctural causality with the representation of women on boards. The second limitation is that the arguments about gender quotas have been relatively separate from studies of institutional antecedents for women on boards, with little attention to the importance of existing national configurations for the introduction of new regulatory policies. As a result, what remains rather unclear is whether gender quotas for corporate boards are sufficient by themselves to achieve a higher number of women on boards (Adams \& Kirchmaier, 2013; Bergstø, 2013), or if they are substitutes or complements in current national configurations.

This study adopts a configurational approach in exploring the joint influence of particular institutional arrangements on diversity on boards and the nature of their complementarities. More exhaustively, we draw on institutional complementarities theory to argue that female representation on boards is the outcome of a conjunctural causal relationship between certain institutional conditions. Furthermore, we investigate the role of board gender quotas in the existing national configurations in terms of their sufficiency and necessity for gender balance on boards. In a comparative perspective, the analysis examines the 27 European Union countries and takes each country as a configuration of specific conditions in four institutional domains: regulatory policies, welfare states, labor, and cultural institutions. In order to explore causal relations and combinatory effects, we employ fuzzy set/Qualitative Comparative Analysis (fs/QCA), a set-theoretic method particularly suitable for studying countries in terms of their multiple memberships in sets of institutional attributes. Our findings reveal a particular configuration of country-level conditions, where the effect of a single condition unfolds only in combination with other conditions, supporting the existence of complementarities and joint causal relationships. In addition, they show that board gender quota legislation is neither a sufficient nor a necessary condition to achieve a higher number of women on boards. Such evidence suggests that their diffusion across countries could be due to institutional isomorphism more than to efficiency or rational reasons.

Overall, this study makes two important contributions. First, after identifying the key institutional domains to be investigated, we provide a systematic theoretical reasoning about the influence of their complementarities in shaping gender balance on corporate board of directors. Second, the use of a configurational approach provides an important methodological contribution. Through fs/QCA, we empirically explore our theory-derived propositions and capture the complex relationships between country-level causal conditions and the representation of women on boards. As a result, our paper refines and expands insights from the extant comparative corporate governance literature, by opening a window for further complementary-based research concerning board composition and demography. For policy makers, it provides some insights that can better drive their choice about which mix of policies might be necessary to improve female representation on boards, and especially in which institutional domains they should be implemented.

The paper is structured as follows. After the literature review, we discuss the theoretical framework and develop our propositions. The following sections describe the research methodology and the main findings resulting from the comparative analysis. Discussion and conclusions are provided in the last section.

\section{LITERATURE REVIEW}

\section{Institutions and Institutional Complementarities}

Institutional theory points out that institutions influence economic activities, organizational structure, and human behavior. Institutions represent the formal (e.g., laws, constitutions) and informal constraints (e.g., taboos, traditions, sociocultural norms) which limit individuals and organizational choices (North, 1990). In other words, they shape the interactions of human beings and form expectations of what people will do (Nugent \& Lin, 1995). (Scott, 1987: 499) defines institutions as relatively resilient "systems of social beliefs and socially organized practices associated with varying functional arenas within social systems," such as work, politics, laws, or regulations. In this vein, any institution "fits into a system of institutions" (Neale, 1988: 245) in a way that they co-exist and co-evolve within a given structure by showing mutually reinforcing characteristics (Ahlering \& Deakin, 2007; Deeg, 2007; Jackson \& Deeg, 2008). Extant research refers to this interdependence with the concept of institutional complementarities. Such a perspective is widespread in the comparative capitalism literature, because institutional complementarities are acknowledged as an important mechanism to explain the diversity of national institutional systems and their resistance to change (e.g., Amable, 2003; Aoki, 2001; North, 1991). For instance, Amable (2000) argues that the overall coherence of a "national model" can be better understood by considering a large set of interacting and interrelated institutional arrangements, rather than isolated institutions. Indeed, when complementarities occur, the existence of an institutional form reinforces the existence of the others: this generates a "dynamic stability" (Amable, 2003).

Generally, complementarity between some elements stems from the circumstance that employing one of them increases the value of employing the others (Aoki, 2001; Milgrom \& Roberts, 1995). From the institutional perspective, complementarities imply that the conjunction of two or more institutions together enhances the performance of a given actor (e.g., organizations or national economies). However, two main logics are embodied in institutional complementarity. When two or more institutions are organized around similar properties and common principles, the logic is similarity. Conversely, the logic of contrast occurs when institutions with different or contrasting properties coexist and one makes up for the deficiencies of the other (Crouch, 2005). While the latter logic implies a sort of compensation, the former refers to the presence of synergies between institutions. Since similar structures make coexistent institutions mutually reinforced (Campbell, 2011), the more aligned and consistent the institutions, the better a given country-level outcome (Amable, 2003).

Although the complementarities-based approach has spread in financial (e.g., Amable, Ernst, \& Palombarini, 2005; Campbell, 2011) and corporate governance research (e.g., Aguilera, Filatotchev, Gospel, \& Jackson, 2008; Garcìa-Castro, 
Aguilera, \& Ariño, 2013; Höpner, 2005; Jackson, 2005; Kang \& Moon, 2012; Rediker \& Seth, 1995; Weimer \& Pape, 1999), it has been neglected in previous studies of diversity on corporate boards. It is in this gap that we place our research.

\section{Institutional Arguments on Gender Diversity on Boards}

The comparative and country-level research on corporate boards has addressed the role of national institutional characteristics in shaping gender diversity on boards of directors, especially with regard to institutional systems (Grosvold, 2011; Grosvold \& Brammer, 2011; Terjesen \& Singh, 2008), infrastructures and public policies (Terjesen, Sealy, \& Singh, 2009), and occupational environments (Adams \& Kirchmaier, 2013).

Grosvold and Brammer (2011) show that countries with generous welfare provisions encouraging women to balance work and family (French and Germanic legal heritages), have fewer women board directors. From a cultural perspective, the authors find that Nordic European and Eastern European culture-oriented countries have a significantly greater percentage of women on boards, owing to their lower levels of gender differentiation. Looking at labor institutions, Adams and Kirchmaier (2013) argue that the presence of (non-executive) women on boards is positively related to female employment, by excluding part-time and unemployed workers. For this reason, the authors underline the importance of policies promoting full-time and family services, since part-time jobs for taking on family responsibilities could undermine women's professional careers. The rationale of focusing on careers to search for the main causes of the under-representation of women on boards is that full participation in the labor market allows women to acquire those competences, experiences, and social capital to sit on boards (e.g., Adams \& Flynn, 2005; Doldor, Vinnicombe, Gaughan, \& Sealy, 2012; Singh \& Vinnicombe, 2004; Terjesen et al., 2009).

Interestingly, a parallel body of literature reveals that female employment and careers are primarily affected by two elements: welfare institutions and cultural/prescriptive norms about gender roles in society. In detail, much research documents that welfare states can fail to release women from family responsibilities and increase unequal gender representation between and within classes or exclude women from influential occupations (e.g., Esping-Andersen, 1990; Mandel \& Semyonov, 2006; Mandel \& Shalev, 2009; Misra \& Moller, 2005). In a similar vein, a number of scholars argue that gender stereotypes and gender schemas in social culture are strong impediments for both female career advancement and representation on boards (e.g., Adams \& Kirchmaier, 2013; Nelson \& Levesque, 2007; Terjesen et al., 2009, 2014; Williams, 2000). In turn, welfare states themselves are found to play a key role in promoting equal opportunities (e.g., Esping-Andersen, 1990, 1999; Grosvold \& Brammer, 2011; Mandel \& Semyonov, 2006; Misra \& Moller, 2005). They significantly impact on gender relations, as well as on the gender division of caring and domestic labor (Orloff, 1993, 1996). These interdependencies are generally supported also by sociologists, who point out that the greatest share of variance in the individual life courses is due to: (1) external social structures linked to the division of labor; (2) the division of labor within households; and (3) the intervention of the state through welfare provisions (Mayer, 2009).

Although not exhaustively, institutional arguments have informed a number of studies about the adoption and diffusion of gender quotas for corporate boards. In Teigen's work (Teigen, 2012), the spread of gender quota legislation is explained according to mechanisms of diffusion, path dependency, and critical conjunctures of distinctive national conditions. Terjesen et al. (2014) argue that the establishment of gender quotas for corporate boards arises from a particular institutional environment, consisting in: (1) gendered welfare state provisions; (2) left-leaning political government; and (3) path-dependent policy initiatives for gender equality. These circumstances of institutional coherence between some country-level factors do not necessarily imply complementarities (Deeg, 2007), albeit complementarities could exist. Conversely, Grosvold and Brammer (2011) discuss that more radical affirmative action should be taken when national cultural heritages are slow to change. In this way, gender legislation on boards might be a supplementary institution, likely making up for the deficiencies of other institutions (according to Crouch, 2005).

Despite their contributions in the institutional understanding of gender diversity on boards, these studies have failed to investigate the effects of the joint influence of institutions on women on boards. In this way, the causal mechanism underlying their relationships has remained less than clear. Moreover, a deeper analysis of the role of gender regulatory policies in the existing national configurations is still needed. There is therefore scope to explore their necessity or sufficiency, as well as their complementary or supplementary function in national institutional systems.

Given their close interconnection and their importance as antecedents of women on boards, welfare, labor, and cultural institutions are particularly suitable to be investigated in terms of complementarities. Accordingly, we need to focus on how gender roles in these three institutional domains are causally and jointly related to gender balance on boards. In line with Schneider and Wagemann (2012), this means that women on boards could be re-framed as the outcome resulting from sets of institutional attributes. For the purpose of this study, in the next section we theoretically argue for the existence of complementarities between welfare, labor, and cultural institutions. Therefore, in order to explore conjunctural causality, we empirically explore our propositions by taking countries as configurations of certain country-level causal conditions, including gender quotas on corporate boards.

\section{THEORETICAL DEVELOPMENT}

The subject of women on corporate boards clearly has social origins, since it evokes a problem of equality in the distribution of opportunity and power in a given social system. As a result, the presence of women in top corporate positions can be conceived as a subset of the overall power structure. If the problem of female under-representation on boards is conceptualized as embedded within broader gender-related social phenomena, women on boards cannot be separated from issues related to women in family, workforce, 
polity/state, and culture. The rationale is that gender itself is an institution intertwined with other institutions (Martin, 2004), as some gendered practices and processes have moved gender in multiple settings and contexts (Acker, 1992). In this frame, "gender is a property of collectivities, institutions and historical processes" (Connell, 1987: 139), and it can be considered "an institution embedded in the workplace, occupations, and occupational environments through formally defined rules, roles, and responsibilities and the 'habitus' of mental structures through which individuals think about their social world" (Terjesen et al., 2009: 324). Accordingly, complementarities between welfare, labor, and cultural institutions can be established on the logic of similarity, because of their similar approaches with regard to the gender perspective. We discuss each in turn.

Among the others, welfare institutions show a profound "gendered" nature. In general, states have had power over other institutions, because they have "codified many aspects of gender into laws or regulations" (Martin, 2004:1259). Institutions reflect the interests of those who have power to make rules and they are not necessarily socially efficient (North, 1990). Thus, men's power over women has been supported by legal institutions for many years (Connell, 1987). Consistent with these arguments, we find that motherhood legislation was enacted so many years earlier than laws for fatherhood rights (Table A1), and it has been particularly resilient to change. The extended length of maternity leave is a common feature in EU countries and it disguises an unbalanced protection of motherhood rather than fatherhood or parenthood. This is clear evidence that states have mobilized gender into welfare institutions. In this way, they have formally institutionalized the prevalent role of women in childcare and housework, by contributing to define gender roles in family and work institutions, as well as in the overall society.

In this vein, a similar gendered logic is embedded in labor institutions. According to Williams (2005), much of gender inequality in occupational environments depends on the fact that the prescriptive norm of the ideal worker (e.g., full-time and full-force for working) comes into conflict with the prevalent role of women in family responsibilities (e.g., full-time and full-force for childbearing and childrearing) in a way that makes them not "un-gendered" norms. For instance, the typical skill regimes of coordinated market economies (CMEs) are found to be more appropriate to the male model of fulltime and continuous employment, by limiting women to certain areas of employment (Mandel \& Shalev, 2009). In view of that, welfare and labor institutions are closely complementary in their "gendered" structures: the presence of more gender unbalanced welfare polices enhances the presence of gender imbalance in labor markets, as well as in prescriptive norms of what is expected by women and men.

Finally, it is widely acknowledged that national cultures have an important role in shaping gender roles in society. Culture stems from human behaviors, recursive practices, norms, and beliefs of a given society. Considering the fundamental sociality of gender (Lorber, 1994), it is rational to assume that, when social actors take "gendered" behaviors, processes and practices, gender itself ends up flowing into national culture. Moreover, since individuals with common cultural backgrounds share convergent mental models, ideologies, and institutions, it is reasonable that those institutions underlie common beliefs and cultural norms on what is expected from individuals (Denzau \& North, 1994). Therefore, if gender is a property embedded in cultural institutions, we can argue that the presence of gender in national cultures enhances the presence of gender in other institutions. The idea is that gender schemas in national cultures may lead to more gendered welfare and labor institutions. In turn, gendered welfare institutions may contribute to intensify the presence of gender imbalance in labor markets, with consequent fewer employment and career opportunities for women.

Taken together, welfare, cultural, and labor institutions complement each other and reciprocally strengthen their gendered nature. The presence of institutional complementarities causes mutual reinforcement and synergistic effects on the distribution of power and opportunity in a given institutional system. According to our rationale, complementarities between these three institutional domains contribute to explain the different performance in terms of female representation on boards between EU countries. Indeed, if women on boards reflect the overall power structure of social systems, we expect that in countries where welfare, labor, and cultural institutions are aligned and highly consistent with an "ungendered" perspective, performance in terms of women on boards will be higher, because of the synergistic effect of complementarities.

Therefore, we suggest the following:

Proposition 1a. The more "un-gendered" cultural, welfare, and labor institutions, the greater the number of women on boards of directors.

Clearly, assuming the existence of institutional complementarities posits that the effects of one institution are contingent on the presence/absence of another (Jackson, 2005). In this vein, complementarities underlie a causal effect and they permit the exploration of possible claims to causality (Deeg, 2007; Kogut \& Ragin, 2006). Investigating causal relations consists in unraveling the necessary and sufficient conditions and combinations of these two types of causes for a given outcome (Schneider \& Wagemann, 2012: 53). When we propose that complementary and aligned institutions have mutually reinforcing effects on female representation on boards, we are assuming an underlying conjunctural causality. This joint causation can be intended in terms of conjunction or combination of multiple conditions where no single cause may be either necessary or sufficient (Kogut \& Ragin, 2006:47; Ragin, 2000). Set-theoretic methods are particularly suitable for exploring these issues and their logic has been applied to empirically explore our propositions.

Conjunctural causal relationship is established when a combination of causal conditions are linked by logical AND operators $\left(^{*}\right)$. For example, $\mathrm{A}^{*} \mathrm{~B}^{*} \mathrm{C}$ implies that a single condition $\mathrm{A}$ plays a causal role only in combination with other causal factors (B and $C$ ). In order to empirically verify the existence of institutional complementarities, the main causal conditions at national level have been selected according to: (1) their significant impact on gender diversity on corporate boards; (2) their capacity to generate complementarities with other institutional domains (Deeg, 2007); and (3) their importance in supporting the gendered nature of institutions. Therefore, for 
each institutional domain we suggest the following causal conditions.

Welfare institutions operate at multiple levels, through several public policies and with different outcomes for the wellbeing of a number of social groups. Consistent with our arguments, we look into the structure of parental leave policies (i.e., paternity, maternity, and parental leave) and the provision of childcare services for assessing the presence of gender in welfare institutions. We are motivated by two aspects. Firstly, if we include parental leave policies for mother, father, and both parents, we can have an important foregoer of the gender division of family and childcare responsibilities. Secondly, the nature of the welfare state is closely related to gendered dimensions of maternity leave, childcare services, and female labor participation (Terjesen et al., 2014). Mother's entitlements and maternity leave were often chosen as examples of the perverse effects of work/family reconciliation policies on female employment and careers (e.g., Aschcraft, 1999; Grosvold \& Brammer, 2011; Mandel \& Semyonov, 2006; Mandel \& Shalev, 2009; Misra \& Moller, 2005; Nelson \& Levesque, 2007). In a comparative perspective, we expect countries with more gender equality-oriented welfare institutions to have: (1) higher levels of childcare services, which release women from their prevalent role in domestic responsibilities; (2) a shorter difference in the lengths of paternity and maternity leave (meaning higher length of paternity leave and not higher length of maternity leave); and (3) a higher level of parental leave. Taken together, these conditions can reveal a more egalitarian perception of gender roles in welfare institutions.

Conversely, given the plurality of inputs underlying cultural and labor institutions (e.g., labor regulation, earnings gap, stereotypes, mental models, recursive practices, behaviors, etc.), their gendered structure is suitable to be assessed in terms of aggregate measure and final outcome. Consequently, we refer to the broader concept of gender equality in society to measure the presence of gender in national culture; meanwhile, we take female employment and part-time female employment as a valid proxy of how gender perspective is embedded within labor markets. Since part-time jobs for taking on family responsibilities may undermine women's professional careers (Adams \& Kirchmaier, 2013), it is important to promote policies for full-time female employment and family services. As a result, we expect that countries with more un-gendered cultural and labor institutions present high levels of gender equality in society, high levels of female employment, but not high levels of female part-time work.

In terms of joint causation between the elected causal conditions, we propose the following empirically testable proposition:

Proposition 1b. High paternity leave, not high maternity leave, high parental leave, high levels of childcare services, high female employment, not high female part-time work AND high gender equality in society are sufficient conditions to achieve a higher number of women on boards.

\section{The Role of Board Gender Quotas in National Configurations}

Configurational and set-theoretical methods are particularly valuable to map countries as configurations of certain causal conditions. This property allows for the theoretical and empirical exploration of the necessary and sufficient function that gender quotas on boards have in the existing national configurations.

A condition is necessary if, whenever the outcome occurs, it is present. It is sufficient if, whenever the condition occurs across cases, the outcome is present. In other words, gender quotas should be a necessary condition if, whenever countries show a higher level of women on boards, they have been enacted. Meanwhile, they should be a sufficient condition if, whenever they occur, countries show a higher number of women on boards. However, if theory-informed Proposition 1a is likely to be true, the joint presence of highly aligned and consistent country-level causal conditions is sufficient to achieve a higher presence of women on boards (Proposition $1 b)$, without requiring any kind of regulation or selfregulation at board level. In other words, their internal consistency and gender neutrality entail superior effects on female representation on boards, because of the institutional complementarities. Since the outcome occurs even in the absence of quotas, in set-theoretic terms this means that gender quotas are not a necessary condition to achieve a higher number of women on boards. However, it is generally and logically true that the presence of mandatory gender quotas at board level implies the presence of more women in board positions. In comparative perspective, this means that, whenever gender quota regulation occurs, we expect countries to have a higher number of women on boards. By definition of sufficiency, in set-theoretic terms this leads to the assumption that gender quotas are a sufficient condition by themselves to have a higher number of women on boards and they represent an alternative path to the outcome of interest. Indeed, several scholars have acknowledged that in countries where particular women-friendly conditions are missing, affirmative action may be a valuable alternative to have more women on boards (e.g., Grosvold \& Brammer, 2011). More formally, we propose the following propositions:

Proposition 2a. Board gender quotas are not a necessary condition to achieve a higher number of women on boards.

Proposition $2 b$. Board gender quotas are a sufficient condition, by themselves, to achieve a higher number of women on boards.

Definitively, if gender quotas on boards represent another sufficient condition, Propositions $1 \mathrm{~b}$ and $2 \mathrm{~b}$ reasonably show two equally effective and mutually non-exclusive pathways to a major presence of women on boards. This circumstance implies equifinality. A result is equifinal when different combinations of causal conditions are linked by logical OR operators (+). For instance, a resultant solution " $\mathrm{A}+\mathrm{B}$ " implies that $\mathrm{A}$ or B equally lead to the outcome.

\section{RESEARCH METHOD}

\section{Fuzzy Set Qualitative Comparative Analysis}

Fuzzy set qualitative comparative analysis (fs/QCA) has been employed here to map countries in terms of their multiple memberships in sets of institutional attributes. The aim was to explore which causal conditions combine and complement 
each other to achieve the outcome under investigation. When the assumptions of configurational theory are involved, this method is more suitable to assess the presence of equifinality and conjunctural causation, rather than statistical investigation (e.g., Fiss, 2007, 2011). Unlike statistical methodology based on linear algebra, QCA relies on Boolean algebra and applies a rigid logic methodology to compare phenomena that vary both qualitatively and quantitatively, for instance in nature (e.g., present or absent) or degree (Ragin, 2002; Rihoux, 2006). Through comparisons across cases, QCA allows us to uncover synergistic, combinatory and equifinal effects by logically reducing the number of possible combinations of causal conditions (Kogut \& Ragin, 2006). For instance, Kogut and Ragin (2006) note that QCA is able to identify eventual logical contradictions: this property represents an important feature to control, even though it does not avoid, the problem of omitted variables, which can make spurious the inferred causality (unobserved sources of variation, such as cultural disposition). Taken together, these advantages have made QCA very widespread in political economy, management and organization studies (Ragin \& Rihoux, 2004; Rihoux, 2006; e.g., Fiss, 2011; Garcìa-Castro et al., 2013; Grandori \& Furnari, 2008; Kogut \& Ragin, 2006).

Fs/QCA requires the transformation of conventional variables into sets "using theoretical and substantive criteria external to the data and taking into account the researcher's conceptualization, definition, and labeling of the set in question" (Ragin, 2008b:16). This process of calibration is particularly significant as countries/cases have to be assessed with regard to their membership in previously defined sets of causal conditions (Schneider \& Wagemann, 2012). Instead of a binary logic (" 0 " for absence and " 1 " for presence), fs/QCA involves the application of fuzzy logic for more fine-grained measures of the attributes under investigation (Fiss, 2007). In particular, we make use of the "direct method" of calibration, by specifying three threshold values: one for full membership to the set, one for full non-membership to the set, and one for the crossover point, or rather, the point of maximum ambiguity where cases have both a membership and non-membership score of .5 in a given set (Ragin, 2000, 2008a). Furthermore, a fuzzy set (A) can be negated and it is denoted by " $\sim A$ " (Ragin, 2008b). The membership in the set

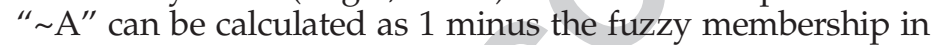
the set " $A$ ". For example, if we have a country with a membership score in the set of "countries with high maternity leave" of .6, the membership score in the negated set "countries with not high maternity leave" is .4. Thus, denoting with $k$ the number of causal conditions, all their possible combinations with their negations are $2^{\mathrm{k}}$ and they represent the rows of a "truth table".

Our analysis is computed with the current version of the fs/QCA software package 2.5 (Ragin, Drass, \& Davey, 2006). By relying on the Quine-McCluskey algorithm, or method of prime implicants, it permits a logical reduction of the detected combinations. After calculating the number of cases with greater than .5 membership score in each combination, the relevant combinations of causal conditions are selected according to their frequency. When the total number of cases is relatively small, the frequency threshold should be 1 or 2 (Ragin, 2008b). We set as acceptable a frequency higher than or equal to 1 . Finally, the validity of the detected combinations is assessed with the calculation of consistency (the measure at which each combination can lead to the outcome) and coverage (the measure of how many cases with an outcome are the results of a particular causal condition). They are calculated with the following:

$$
\begin{aligned}
& \text { Consistency }(X<Y)=\sum \min (X, Y) / \sum X \\
& \text { Coverage }(X<Y)=\sum \min (X, Y) / \sum Y
\end{aligned}
$$

where $X$ is the membership score of cases in a given configuration of causal conditions and $Y$ is the membership score of cases in the outcome set. The minimum recommended threshold to accept a solution as consistent is .75 (Ragin, 2006, 2008a).

\section{Selection Criteria of Cases and Conditions}

In line with Kogut and Ragin (2006), the selection of cases and conditions was particularly consistent with our substantive and theoretical interests and it required a systematic dialogue between ideas and evidence. While the selection of causal conditions underlies a reasoned synthesis of theoretical arguments and empirical evidence previously discussed, the choice of comparing the EU countries ${ }^{1}$ stems from two main motivations. On the one hand, EU countries show different performance in terms of female representation on boards, according to their different economic, cultural, and regulatory environments (Kang, Chen, \& Gray, 2007). Given this heterogeneity, it is very challenging to explore whether a relative superiority of a particular institutional model exists. On the other hand, the European Union is very committed in the debate about gender diversity on boards, as it has asked publicly listed companies to increase the female representation on boards to 40 percent by 2020 . While some countries have introduced some form of regulation, others have opted for voluntary or recommendatory initiatives (Huse \& Seierstad, 2014). Furthermore, recognizing the disproportionate involvement of women in part-time work and the persistence of the traditional caregiver model, the European Union has asked member states to provide a major number of inexpensive and high-quality childcare services, suitable forms of parental leave for both men and women, and binding quotas for increasing the presence of women in positions of responsibility. These circumstances have created a common purpose on how to have more women on boards, but they require further investigation. A key question would be whether regulatory policies enacted in some countries might be transferable to others, and the role that institutional complementarities may have in shaping female representation on boards.

In this study, countries are analyzed as configurations of welfare, labor, and cultural institutions. We also include regulatory policies about board gender quotas to investigate their role in the existing national configurations. With the aim of electing the causal conditions to be included in the analysis, the three main institutional domains have been detailed in specific national attributes. While welfare institutions include measures about maternity leave, paternity leave, parental leave, and childcare services, labor institutions are expressed in terms of the total amount of female labor force and the percentage of women involved in part-time work. National 
culture corresponds to the overall level of gender equality in society and it can be measured using the Global Gender Gap Index. Finally, regulatory policies refer to the form of regulation for female participation on board (gender quotas or corporate governance codes). Moreover, in order to express these conditions quantitatively, we conducted a documentary analysis of the main legal texts, statistics, and documents which contain information about the phenomenon under investigation (Bailey, 1994; Payne \& Payne, 2004; Scott, 1990). They are mainly provided by the Council of Europe Family Policy Database (2009); OECD Family Database (2012); Margherita, O'Dorchai and Bosch (2009); EU-SILC (2012), and World Economic Forum (2013). In this way, a systematic review of legislation for each one of the 27 European Union countries was made.

Tables A1 and A2 in the appendix show our data matrix and descriptive statistics. In the following section, we detail the description of both causal conditions and outcome and we discuss the criteria of their calibration in fuzzy sets.

\section{Data Description and Set Calibration}

Outcome Measures. A higher number of women on boards is the outcome of our interest. Data about women on boards were taken from the European Commission's database on women and men in decision making (European Commission, 2012a, 2012b), containing information on 582 companies, corresponding to 5,910 board members. The companies covered are the largest (primarily blue-chip index members) publicly listed ${ }^{2}$ companies in each of the 27 European member states (maximum 50 per country). As described in the methodological section of the European Commission database (European Commission, 2014), in countries with unitary (one-tier) systems, the board of directors is counted as including non-executive and executive members and data cover the main board plus the members of the most senior executive body (e.g., executive committee). In countries with two-tier systems, data cover executive and non-executive members of both boards but only the supervisory board is counted. Individuals sitting on more than one decision-making body are counted only once and employee representatives are excluded. In order to express how many women there are on boards compared with the total number of board members, we use the percentage and not the absolute values. Moreover, we take into account data from both executive and nonexecutive board members, as we are interested in the attainment of those positions held by women through their career paths, rather than their performance in the boards of directors. While to achieve perfect balance between men and women requires the presence of 50 percent women on the board, much research has demonstrated that the critical mass of women directors is reached when boards of directors have at least 30 percent women. The President of the European Commission invited publicly listed companies to voluntarily increase women's presence on corporate boards to 30 percent by 2015 and 40 percent by 2020, while, following the example of Norway, the European Women's Lobby recommended European member states to adopt legislation requiring certain companies to have 40 percent of women on their boards of directors by 2015 and 50 percent by 2020 (Armstrong \& Walby, 2012). By applying these substantive guidelines as external criteria to calibrate measures of sufficient or insufficient presence of women on boards in a country, we considered 30 percent as the full membership threshold for sufficient gender diversity on boards. Although this does not constitute adequate proof of equality, it does represent a significant achievement. Thus, the three thresholds chosen to calibrate our outcome are: 30 percent for full membership, 20 percent for the crossover point of maximum ambiguity, and 10 percent for the full non-membership. For these reasons, we specify this target as the set of "EU countries with a higher number of women on boards".

Maternity Leave ${ }^{3}$. Since parental leave can be designed in very different ways, we have adopted careful criteria to make welfare institutions between EU countries more comparable. In particular, only the statutory amount for maternity and paternity leave was considered. Moreover, thanks to fuzzy logic, we are able to take into account the level of generosity of maternity and paternity leave by using a more fine-grained measure of these attributes, rather than their mere presence (1) or absence (0). Finally, even though uptake of leave can differ greatly from that allowed for by legislation, the laws provide a condition that precedes the possibility of actually taking leave. Thus, they mirror the gendered nature of welfare policies which potentially emphasize the prevailing role of women in family responsibilities. The calibration was done considering a crossover point of maximum ambiguity of 150 days, approximately corresponding to the minimum value of days recommended by the European Parliament. The thresholds for full membership and full non-membership were defined with an equal distance interval from the crossover point: 250 days and 50 days, respectively. The result is a target set of "EU countries with high maternity leave".

Paternity Leave ${ }^{4}$. A majority of members of the EU Parlia- Q5 ment have approved a full paid paternity leave of at least two weeks (Thomsen \& Urth, 2010). For this reason, the paternity leave set calibration was computed by considering the minimum number of days recommended by the European Parliament as the full membership threshold, i.e. 15 days. Consequently, the crossover point and the full nonmembership threshold were defined with an equal distance interval from the full membership value: 9 days and 3 days, respectively. It will be the target set of "EU countries with high paternity leave".

Parental Leave ${ }^{5}$. In our analysis we considered only paid parental leave as the sum of both mother and father quotas. From Directive 2010/18 of the Council of Europe we know that a minimum period of four months of parental leave for each parent is recommended (European Union, 2010). Therefore, in order to consider a country with a significant provision of parental leave, we established a full membership threshold of 240 days, corresponding to about eight months if we consider both parents. As above, the crossover point of maximum ambiguity and the full non-membership threshold are 140 days and 40 days, respectively. We called this target the set of "EU countries with high parental leave".

Childcare Services ${ }^{6}$. This concept refers to the availability of childcare services across EU countries. Data were taken 


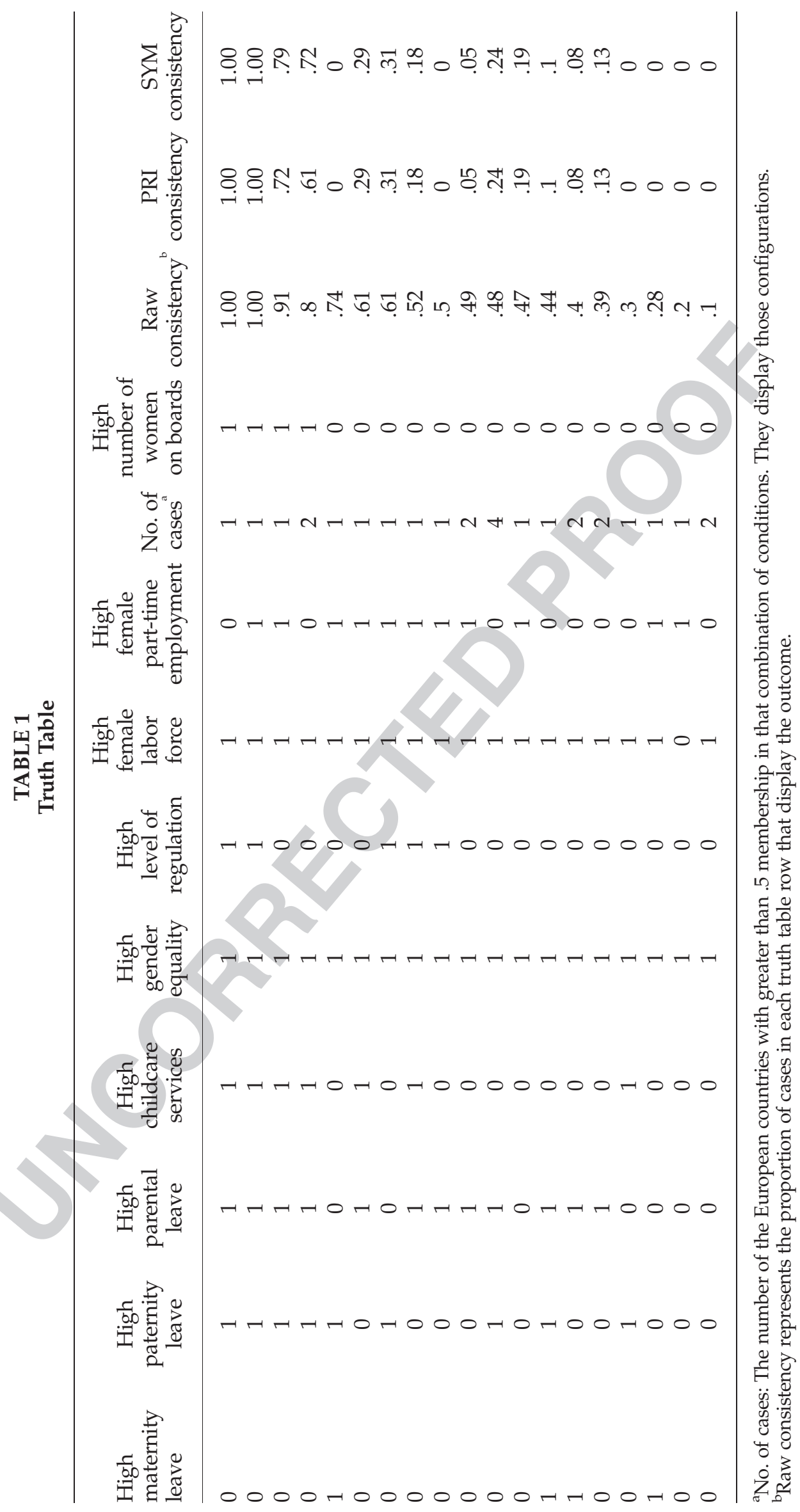


TABLE 2

Truth Table Analysis

Model: HighWOB $^{\mathrm{a}}=f\left(\operatorname{HighPALp}^{\mathrm{b}}, \mathrm{HighML}^{\mathrm{c}}, \mathrm{HighPL}^{\mathrm{d}}, \mathrm{HighFCH}^{\mathrm{e}}, \mathrm{HighFlf}^{\mathrm{f}}, \mathrm{HighGE}^{\mathrm{g}}, \mathrm{HighREG}^{\mathrm{h}}\right.$, HighFpt $\left.^{\mathrm{i}}\right)$

Rows: 19

Algorithm: Quine-McCluskey

\section{--- COMPLEX SOLUTION ---}

Frequency cutoff: 1

Consistency cutoff: 0.80

$\begin{array}{ccc}\text { Raw } & \text { Unique } & \\ \text { coverage } & \text { coverage } & \text { Consistency }\end{array}$

HighPALp * $\sim$ HighML * HighPL * HighFCHs * HighFlf * HighGE

.49

.49 .85

Solution Coverage: 49

Solution Consistency: .85

Cases with greater than .5 membership in terms of the solution: Slovenia, Sweden,

Finland, Denmark, France

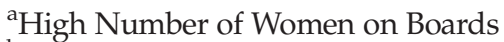

${ }^{\mathrm{b}}$ High Parental Leave

'High Maternity Leave

${ }^{\mathrm{d}}$ High Paternity Leave

eHigh Formal Childcare Services

${ }^{\mathrm{f}}$ High Female Labor Force

gHigh Gender Equality

${ }^{\text {h}}$ High Regulation

${ }^{\mathrm{i}}$ High Female Part-Time Employment

jUnique coverage is the rate of the sample that is covered by this specific pathway

FIGURE 1

Representation of the Solution

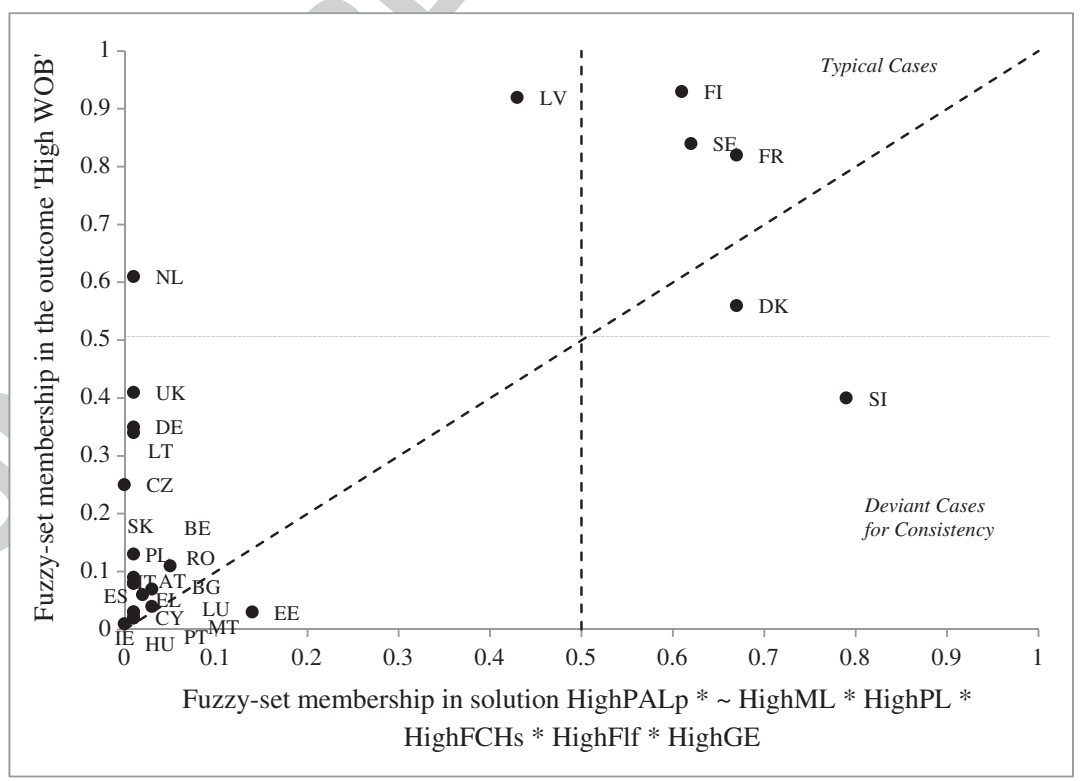

from Eurostat, the statistical office of the European Union. For our analysis, data relating to formal services with duration higher than or equal to 30 hours for children aged less than
3 years (0-2 years) were chosen. According to the objectives of the Barcelona Summit, member states aimed to remove obstacles to female participation in the labor force and to meet 
the demand for more childcare services for at least 33 percent of children less than 3 years of age. This target represents our threshold of full membership. Following the principle of range equality, the crossover point was established at 20 percent, as this percentage is neither too far nor too close to the Barcelona objectives. In a similar vein, the full non-membership was defined as 10 percent, as it does not get close to meeting these objectives. This will be the target set of "EU countries with high level of formal childcare services".

Female Participation in the Labor Market. Data on female employment was taken from the Global Gender Gap Report of the World Economic Forum (2013) and include a measure of the proportion of a country's working-age population (15-64) that engages in the labor market. The agenda of Europe 2020 proposes as a main goal the achievement of a general employment rate for women and men of 75 percent for the 20-64 years age group, as 75 percent is estimated to be full employment where everybody who wants to get a job should be able to do so. At the same time, the Lisbon Strategy aimed to achieve by 2010 female employment of 60 percent. In line with EU recommendations, we propose a threshold of full membership at 65 percent of female employment. That represents a middle point between what had to be done and what may be done in the coming years. Then, the crossover point of maximum ambiguity and the full nonmembership threshold are 45 percent and 25 percent, respectively, with equal intervals from the crossover point. We called this target the set of "EU countries with high level of female labor force".

Female Involvement in Part-Time Jobs. Female part-time employment rates were taken from the Global Gender Gap Report of the World Economic Forum (2013) and represent the percentage of women of the total female employment in a country involved in part-time jobs. Since 1997 (Directive 81), the European Union has urged the removal of discrimination against part-time workers and the promotion of quality Q6 part-time work (European Commission, 2010). Women are the majority of part-time workers in the EU, with 32.1 percent of women working part-time compared with only 9 percent of men. This circumstance has a negative impact on female career progression, training opportunities, and the gender pay gap (Burri \& Aune, 2013). Then, in order to consider a country as having a significant female involvement in part-time work, we argued that a value of 35 percent of the whole female labor force indicates a strong imbalance between the way in which women and men stay in the labor market. Following the principle of range equality, the crossover point was established at 20 percent, and the threshold for full non-membership was defined as 5 percent. This will be the target set of "EU countries with high level of female part-time work".

Global Gender Gap Index. Data regarding the global gender gap index were taken from the Global Gender Gap Report of the World Economic Forum (2013). This index was developed to capture the magnitude of gender-based disparities. In particular, it seeks to measure important aspects of gender equality across four key areas, namely health, education, economics, and politics, and it ranks a large set of countries in accordance with their scores in gender equality between 0 and 1 .
For our aims, this index represents a suitable aggregate measure to assess the presence of gender equality in societies. Firstly, it is independent from the countries' levels of development. For example, it is clear that rich countries can offer more education and health opportunities to all members of their societies. Secondly, it is based on outcome rather than inputs. This means that its focus is on the results achieved in outcome indicators (e.g., the number of legislators, managers, or senior officials), rather than in policy indicators (e.g., length of maternity leave). According to the logic with which the global gender gap index has been constructed, we have calibrated cases by establishing a threshold of .5 for the crossover point of maximum ambiguity, 1 for full membership and 0 for full non-membership. The result is a target set of "EU countries with high level of gender equality".

Forms of Regulation. Data regarding the legal or voluntary regulation of female representation on boards were taken from several sources, such as the European Commission's database (2012a), the European Commission National Factsheets (European Commission, 2013), Catalyst Report (2014), Terjesen et al. (2014). By recognizing that the forms of regulation differ greatly between EU countries, we made a particular distinction between countries with gender board quotas and countries with forms of self-regulation (such as codes of good governance). In this way, we assigned the value of 1 to EU countries where gender quotas occur; .5 to EU countries with some forms of self-regulation; and 0 to countries that do not adopt any of the foregoing. However, if a threshold of the crossover point is established at .5, for example, the calibration becomes problematic, as several countries present this value and their membership score in the fuzzy set would be .5. In this way, cases can be conceptually ambiguous, because they are neither in nor out of the target set (Ragin, 2008b). For this reason, we established that .55 could be the crossover point of maximum ambiguity. Following the principle of range equality, the thresholds for full membership and full nonmembership were defined with an equal distance interval from the crossover point. In particular, the former corresponds to a level of regulation more than or equal to 90 percent (.9), the latter corresponds to less than or equal to 20 percent (.2), because it does not satisfy in any way the aim of gender balance on boards. This target set corresponds to the set of "EU countries with a high form of regulation for female representation on boards".

\section{ANALYSIS AND RESULTS}

The truth table resulting from calibrations is shown in Table A3. The analysis was made at two levels. Firstly, we individually analyzed the sufficiency and necessity of each causal condition of a higher number of women on boards. Afterwards, we proceeded to examine their combined sufficiency in order to explore joint causation and equifinality.

By definition, a necessary condition represents a superset of the outcome set, in a way that no case could show the outcome without the condition. Hence, the fuzzy membership scores in the causal conditions must be greater than or equal to fuzzy membership in the outcome (Ragin, 2008b). The consistency of necessary conditions is the result of the following: 


$$
\operatorname{Consistency}(Y<X)=\frac{\sum \min (X, Y)}{\sum Y}
$$

To reduce the likelihood of true logical contradictions, the consistency threshold for considering a condition as necessary needs to be .90 or higher (Schneider \& Wagemann, 2012). As shown in Table A4, the conditions that pass this threshold are: (1) high level of labor force (1.00); (2) high level of gender equality (.98); and (3) high level of maternity leave (.92). However, the different size of sets requires an evaluation of the corresponding values of coverage in order to check for relevance and triviality. The formula of coverage of necessary conditions is useful to establish whether the outcome set is much smaller than the condition set. It is:

$$
\text { Coverage }(Y<X)=\frac{\sum \min (X, Y)}{\sum X}
$$

Figures A1-A3 report the graphical representations of the distributions of countries in each necessary condition. Since the greater the value of coverage, the greater the relevance of necessary conditions, we should consider "not high maternity leave" as a necessary condition to achieve a higher number of women on boards, because it is fully consistent and has a greater value of coverage than the others (.39). Nevertheless, there is another form of triviality that should be avoided, i.e. when the necessary condition might be a constant, because it occurs in most of the cases under investigation (Schneider \& Wagemann, 2012). To check relevance without triviality, we made use of the formula proposed by Schneider and Wagemann (2012):

$$
\text { Relevance of Necessity }=\frac{\sum(1-x)}{\sum(1-\min (x, y)}
$$

According to Schneider and Wagemann, if a necessary condition is a constant, the resulting values of relevance are close to 0 and they indicate triviality; conversely, they are close to 1. Table A4 shows that for each condition that passes the threshold of consistency, we obtained very low values of relevance. Definitively, these conditions cannot be considered relevant, due to their constancy.

Furthermore, we tested the individual sufficiency of each causal condition employed in our analysis. Interestingly, we found that none of them can be considered a sufficient condition leading by itself to a higher number of women on boards. Indeed, their consistency values are not considerably acceptable for establishing individual sufficiency. In line with the criteria of calibration, the condition "high level of regulation" refers to the presence of gender quotas at board level. Its consistency value is around .50, showing that gender quotas are not a sufficient condition by themselves to achieve a higher number of women on boards. The corresponding results are shown in Table A4.

The existence of necessary but non-sufficient conditions (individually) implies a conjunctural causation because they could be sufficient if combined with others (Schneider \& Wagemann, 2012). In order to explore conjunctural causation, we performed the joint analysis of sufficient conditions and the logical minimization of the truth table. After calculating all the possible combinations $\left(2^{8}\right)$, the number of cases for each configuration was determined by selecting a frequency threshold of 1.0. The outcome was found by setting "countries with a higher number of women on boards" to 1 for each configuration (row) whose consistency level meets and/or exceeds the threshold of .75, as shown in Table 1.

Since there were not logical reminders (logically possible configurations which were not empirically observed across cases), in Table 2 we report the results corresponding to $\mathbf{T} 2$ the complex solution, or rather, that solution which limits the analysis to the observed cases without counterfactuals. For this reason, the complex solution is also defined as a conservative solution (Schneider \& Wagemann, 2012). Conversely, when certain types of assumptions are made about logical reminders, the analysis produces even the parsimonious and intermediate solutions, as broadly described elsewhere (e.g., Ragin, 2008a, 2008b, 2009; Schneider \& Q7 Wagemann, 2012),

Our complex solution provides a single configuration of sufficient country-level conditions leading to a higher number of women on boards. This pathway displays a consistency higher than the threshold of .85, which coincides with the overall solution consistency, while the coverage shows a value of .49, which is very acceptable. More in depth, this configuration corresponds to the EU countries with high paternity leave, not high maternity leave, high parental leave, high level of childcare services, high level of female labor force and high level of gender equality. They are Slovenia, Denmark, Sweden, Finland, and France, which have greater than .5 membership in this configuration ).

\section{DISCUSSION AND CONCLUSION}

To address the lack of a complementary-based approach in the literature about gender diversity on boards, this study investigates whether and how certain institutional domains in national environments are causally and jointly related to a greater presence of women on boards and explores the nature of their complementarities. Alongside, it seeks to empirically assess the role of board gender quotas in the existing national configurations to infer more about the reasons for their adoption and diffusion. The core assumption in Proposition 1a draws on institutional complementarities theory to argue that the more "non-gendered" the welfare, labor, and cultural institutions, the higher the number of women on boards.

The empirical evidence provides support for a number of our propositions. Particularly, Proposition $1 \mathrm{~b}$ has been supported by the presence of countries with particular national configurations where high paternity leave, not high maternity leave, high parental leave, high level of childcare services, high level of female labor force and high level of gender equality are sufficient conditions to achieve a higher number of women on boards. Moreover, these results support that, taken jointly, certain institutional arrangements in welfare, labor and cultural environments are causally related to female representation on boards of directors. However, we cannot infer the same for the condition "not high level of female part-time employment", since it is missing in the unique configuration. This was probably due to its lack of consistency with the other conditions, because there are countries, such as Denmark and 
France, where female part-time employment is higher than in the others, even though their values are closer to the crossover points than to the threshold of full-membership in the set of "high level of female part-time employment".

In line with our expectations in Proposition 2a, board gender quotas are found not to be a necessary condition to achieve a higher number of women on boards. In practical terms, there are countries where the particular configuration of national institutions is sufficient to foster the presence of women in top corporate positions without enacting gender quotas at board level (i.e., Slovenia, Denmark, and Sweden). However, contrary to our assumption in Proposition $2 b$, we find that board gender quotas are not a sufficient condition to achieve a higher number of women on boards. Bearing in mind the definition of sufficient conditions, this result is supported by the existence of countries which do not show a higher number of women on boards, despite the enactment of mandatory gender quotas (e.g., Belgium, Spain, and Italy). As gender quotas are found not to be a sufficient condition by themselves, our findings do not support the existence of equifinal pathways which can lead to greater female representation on boards. As a result, they cannot be considered as equally effective and mutual substitutes of a "national model" in which gender equality is radically embedded in each institutional domain.

F1 In Figure 1 we graphically display our findings. As sufficiency implies that conditions are subsets of the outcome, the membership score of a country in the sets of the former have to be equal to or smaller than its membership in the set of the latter. This means that all cases should be above or on the main diagonal. Interestingly, the $X Y$ plot shows some qualitative differences between countries. By discussing these differences, we propose comparative within-case studies to corroborate our assumptions and assess the role of board gender quotas within the existing national configurations.

According to the principles of post-QCA cases studies described in Schneider and Wagemann (2012), "typical cases" above the main diagonal are those which satisfy high value of consistency and coverage in both the sufficient configuration and the outcome (Finland, Sweden, and France), while cases with good values in the sufficient solution, but not in the outcome set, are labeled "deviant cases for consistency" (Slovenia). Denmark represents a very difficult case: as it stays below the main diagonal, Denmark contradicts the statement of sufficiency despite its membership in both solution and outcome. This circumstance substantiates what has been noted elsewhere, exactly that Denmark represents a "deviant" case among the Nordic countries (Teigen, 2012), due to its more limited gender equality tradition in politics. In fact, the skepticism about gender quotas on boards has led Denmark to opt for soft regulation.

By focusing on typical cases, Finnish, French, and Swedish national configurations show that the high gender neutrality and consistency between their institutions are sufficient to lead to more women on boards. In line with the results of Grosvold and Brammer (2011), most of these typical cases are primarily Nordic European culture-oriented countries, where the embeddedness of gender equality in national culture is widely recognized. Conversely, we reveal that France has a good performance in terms of female representation on boards. While this finding diverges from the evidence that generous welfare institutions in countries with French and Germanic legal heritages lead to lower levels of women on boards (Grosvold \& Brammer, 2011), it is really consistent with our assumptions. Indeed, France, Sweden, and Finland share the highest provision of childcare services, highest paternity and parental leaves, and highest level of female employment between EU countries. Taken together, this evidence highlights that assessing the influence of welfare institutions on women on boards requires an additional focus on their level of gender equality more than on their mere generosity. The presence of more gender-neutral institutions, which are aligned and mutually reinforcing, enhances the presence of un-gendered structures in power institutions and leads countries to better perform in terms of gender diversity on boards. Under our rationale, it is not surprising that Sweden, France, and Finland present some of the highest rates of women on boards between EU countries. Given the assumption of institutional complementarities underlying the theory-informed Proposition 1a, it is reasonable to conclude that the less the gender perspective is embedded in these institutional domains, the higher the presence of women on boards.

Although they were not necessary in this "ideal" configuration, gender quotas for boards of directors have been enacted in Finland and France. This circumstance suggests that in these countries the implementation of gender quotas might be due more to diffusion or legitimization reasons rather than to rational sources. Kogut \& Ragin (2006: 47) argue that "diffusion depends upon existing configurations. This means that if northern European countries share a thousand years of institutional and ideational diffusion, they are more likely to adopt institutions from each other than from other regions because the institutional compliance is more likely." Certainly, the introduction of board-level gender quotas has become a socially expected policy following Norway's initiative, and their diffusion among EU countries seems to be not so much related to rational and efficiency reasons. Even though gender quotas are a near zero-cost policy for nations (Brogi, 2013), other costs may arise for companies. In this vein, several scholars contend that the introduction of board-level gender quotas can have ambiguous effects on firm performance (e.g., Ahern \& Dittmar, 2012; Ferreira, 2014; Terjesen et al., 2014; Toomey, 2008), but isomorphic behaviors or reasons of social legitimacy tend to disguise these aspects. As shown in the recent work of Seierstad, Warner-Søderholm, Torchia, and Huse (2015), the EU represents a key influential actor in political debates on potential regulations for female representation on boards. The EU pressure has been particularly visible in the case of Germany. Despite great skepticism and strong political disagreement about gender quotas, Germany has recently enacted quotas law: 30 percent of supervisory board positions must be held by women from 2016. These insights underline an important implication: if reasons of institutional isomorphism or social legitimization prevail, we can expect that changes might occur in other particularly skeptical countries (e.g., Denmark), as well as in countries like Finland or France, where the institutional setting is already favorable to having more women on boards.

Another relevant implication of our research is related to the fact that the presence of institutional complementarities can explain why introducing a new institution into a given system 
might fail to achieve the intended objective (Deeg, 2007). On the one hand, our findings give evidence of what has been noted in previous research (e.g., Adams \& Kirchmaier, 2013; Bergstø, 2013): if gender quotas contribute to reinforce gendered or negative attitudes toward women, they cannot be very effective and they need to be combined and complemented with more gender-neutral family laws and policies promoting women at all levels of their career advancement, not just at board level. On the other hand, the high complementarity between institutions in a "gendered" perspective might contribute to slow down the change, making gender quotas not a sufficient condition by themselves to achieve a greater presence of women on boards. This might be the case for countries, such as Italy, Belgium, or Spain, where gender quotas are not combined with a national environment particularly devoted to gender equality. For instance, Italy is not considered as a gender-egalitarian society and its performance in terms of women in board positions is rather disappointing (Seierstad et al., 2015).

Overall, this study makes several contributions. For scholars, we refine and expand insights from the extant literature on gender diversity on corporate boards. We make a further step in this stream of research by finding theoretical and empirical support for the existence of complementarities between the main institutional domains affecting women on boards. In this way, we open a window for future research which might address a plurality of phenomena related to corporate boards in a configurational and complementaritiesbased approach (e.g., composition and demography of corporate boards, the effectiveness of corporate governance design, or corporate governance practices). We also prepare the ground for future investigations on institutional change for women on boards. Indeed, "if institutional complementarities exist, then change in one institution should precipitate change in complementary institutions" (Deeg, 2007: 622). By taking a configurational perspective, this study also makes an important methodological contribution to the corporate governance literature. Set-theoretic methods enable the empirical investigation of the theoretically derived existence of conjunctural relations between certain causal conditions. By employing them, we provide an empirical demonstration of the joint influence of welfare, labor, and cultural institutions on the presence of women on boards. Moreover, fs/QCA allows for a depth comparison between countries, particularly useful to gain relevant insights about the mechanisms of the diffusion/adoption of board gender regulation.

From a practical perspective, this research presents notable implications for policymakers. Our insights may better drive their choice about which mix of policies might be necessary to improve female representation on boards, and especially in which institutional domains they should be endorsed. If the determinants of female representation on boards stem from particular institutional arrangements, the aim should be to achieve gender neutrality in each institutional domain. Given the high interconnection between welfare, labor, and cultural institutions and the mutually reinforcing effects of their complementarities, it may be more effective to implement policies involving all these institutional domains, rather than introducing regulatory policies just at board level. In addition, as quota laws may have ambiguous effects on boards of directors and firm performance (see, e.g., Ahern \& Dittmar,
2012; Ferreira, 2014; Terjesen et al., 2014; Toomey, 2008), more rational-driven policies might consider the actual necessity and sufficiency of gender quotas in the existing national configurations.

However, this study suffers some limitations. First, even though fs/QCA methodology allows for the exploration of causal relationships, complementarities and synergistic effects, it relies mainly on the subjectivism of researcher choices. To contain this limitation, we made our criteria in the selection of cases, causal conditions, and calibration particularly transparent. Second, we focus mainly on institutional environments without taking into account the characteristics of national companies and corporate governance systems and practices. Our choice stems from the evidence that legal and cultural environments play the most role in shaping gender balance on boards rather than governance and business systems (Grosvold \& Brammer, 2011). However, as the national differences in types and systems of corporate governance may have some effects, future research could investigate the existence of complementarities between firm-level and corporate board-level characteristics in a comparative perspective and their joint influence on women on boards. Third, our analysis included the difference between the implementation of gender quotas and soft regulation, but the enforcement of the law varies greatly. Clearly, when the enforcement is strong as in Norway or France, then there is a direct relationship between the number of women on boards and quota. However, when the enforcement is weak - as in Spain - the consequences may be feeble. Further in-depth case studies could overcome this limitation by exploring the role of enforcement with regard to the actual necessity and sufficiency of gender quotas on boards. Finally, as our sample was limited in size, we did not perform additional statistical tests. Future development of this research could include European and non-European countries. In doing so, it would be particularly interesting to deepen our insights relating to the mechanisms of adoption and diffusion of gender regulatory policies for boards of directors.

To conclude, through this research we contribute to conceptualizing the problem of female underrepresentation on boards as embedded within broader gender-related social issues. According to our assumption, we propose women on boards as the outcome of a set of complementary institutions and re-frame them in terms of set relations. In line with Amable (2000), acknowledging the effects of interacting institutions is very important for theoretical research and policy recommendations. Thus, we reveal that the more the gender perspective is embedded in several institutional domains, the lower the presence of women in the overall power structure and, therefore, in top corporate positions. Therefore, legislative initiatives should consider that the introduction of gender quotas at board level might not be sufficient if gender inequality persists in other institutions.

\section{ACKNOWLEDGEMENTS}

The authors would like to thank the Associate Editor and five anonymous reviewers for their valuable comments and suggestions that significantly improved this manuscript. 


\section{NOTES}

1. The European Union was established on 1 November 1993 with 12 member states. Their number has grown to the present 28 through a series of enlargements. Since we compared EU countries from January 2013 to June 2013, we had to exclude Croatia from the analysis because its entry in the European Union has occurred on July 2013. Thus, the number of cases we employed in our analysis is 27 , but they constitute de facto a population rather than a sample.

2. Publicly listed means that the shares of the company are traded on the stock exchange. The largest companies are taken to be the members ( $\max .50)$ of the primary blue-chip index, which is an index maintained by the stock exchange covering the largest companies by market capitalization and/or market trades (European Commission's Database, 2012a). More in depth: a) in cases where the blue chip index covers a large number of companies, only the 50 largest are taken into account; b) in cases where the blue chip index does not cover enough companies, companies with the next largest market capitalization are taken into account when possible; c) non-national companies (i.e. those registered in another country according to the ISIN code) are excluded so that the data for each country cover only companies registered in that country (European Commission, 2014).

3. According to OECD's definition, maternity leave is an employment-protected absence for employed women in a period around the time of childbirth. As the aim is to protect the health of the mother and newborn child, this leave is generally taken prior to (pre-birth leave) and immediately after childbirth (postbirth leave). Most EU countries have compulsory pre-birth leave and they provide public income support payments during this period. In some countries, maternity leave is included in general parental leave schemes (e.g., Sweden, Germany).

4. Paternity leave is an employment-protected absence for employed fathers. It is much shorter than maternity leave and it usually starts soon after the birth of child. Because of the short period of absence, workers on paternity leave often continue to receive full wage payments. In some countries, paternity leave is part of the parental leave schemes (father's quotas), rather than established as a separate right. In our analysis, we considered paternity leave available to fathers only.

5. Parental leave provides paid or unpaid leave to parents for child care. It is often supplementary to specific maternity and paternity leave periods, and it usually follows the period of maternity leave.

6. Data were provided by the EU-SILC and the European statistics on income and living conditions, the reference source for comparative statistics on income distribution and social inclusion in the European Union. Formal childcare services include four EUSILC survey variables, namely pre-school or equivalent education, compulsory education, centre of childcare services outside school hours, and day-care centre of child care, organized or controlled by public or private sector. Formal childcare services are classified by age group and duration as the percentage of the population of each age group.

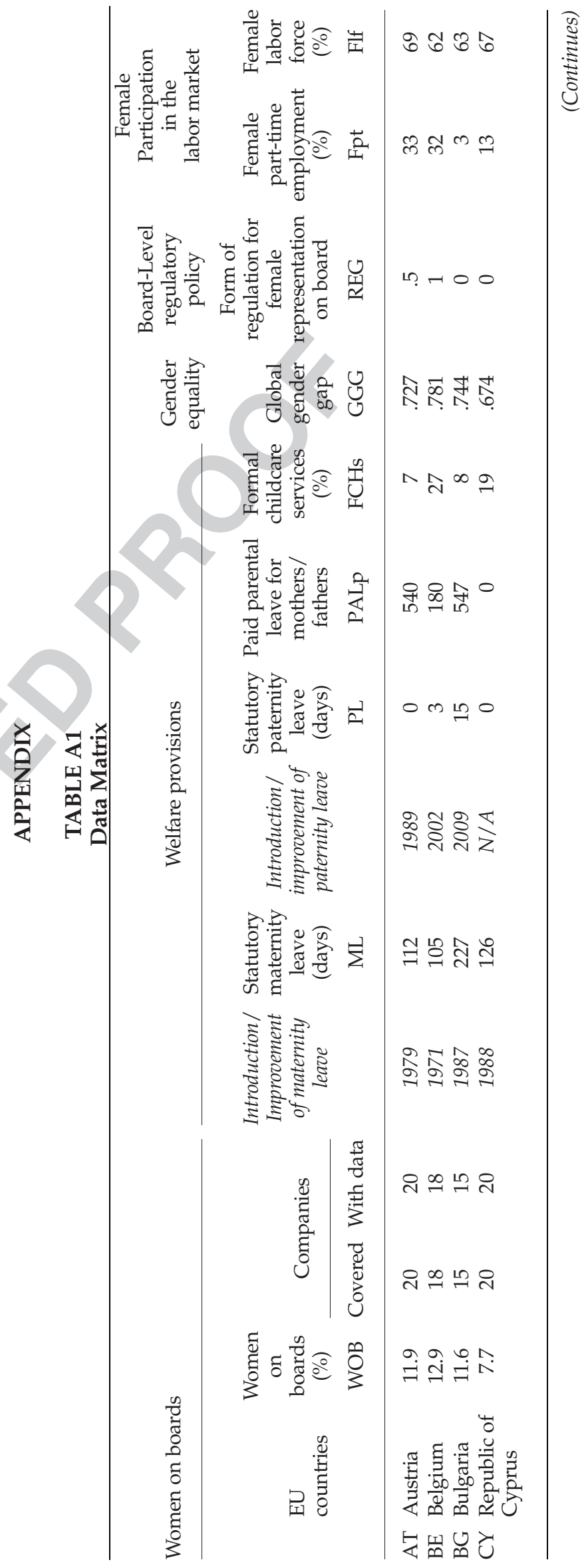




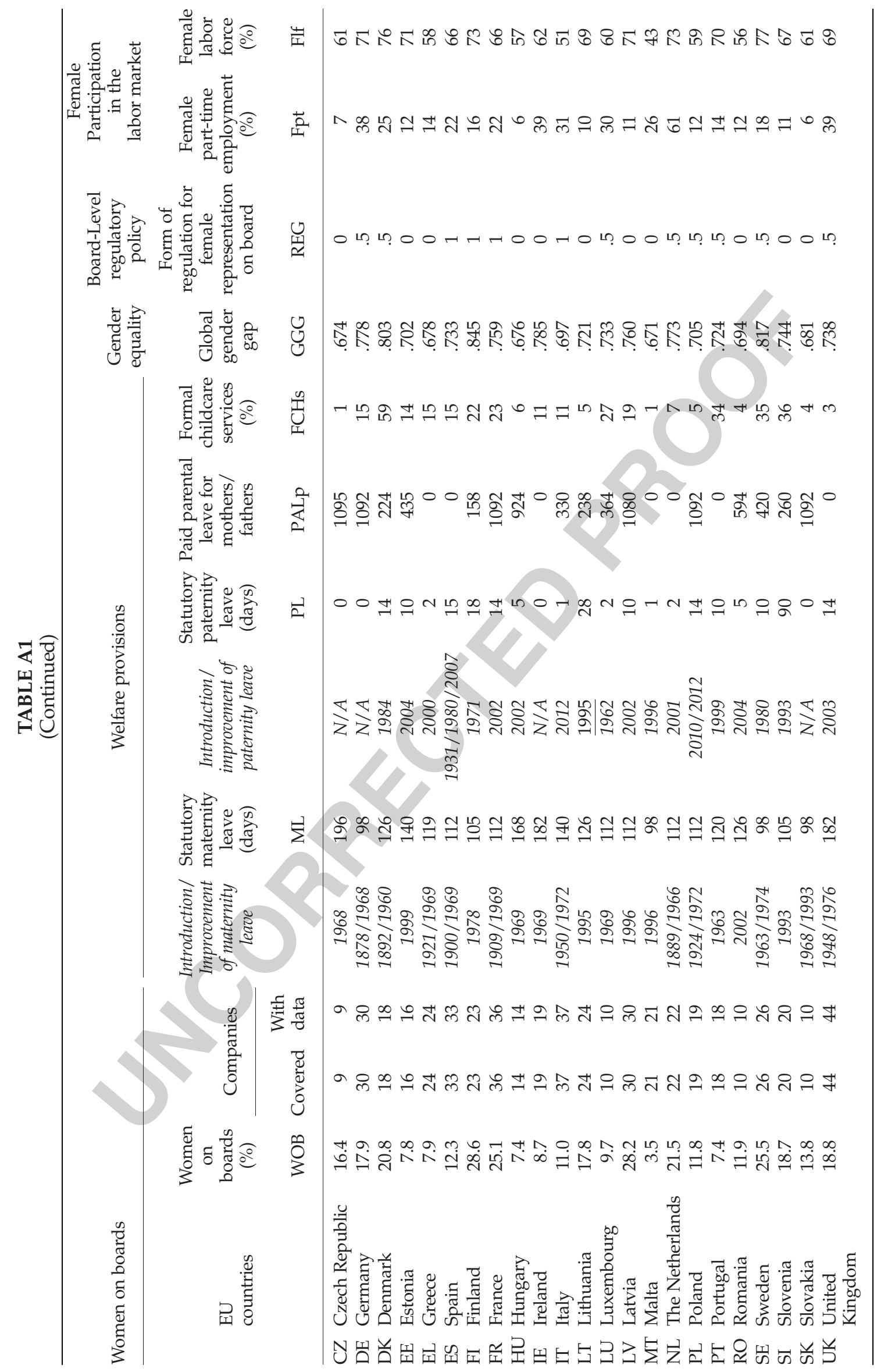


TABLE A2

Descriptive Statistics

Criteria of calibration

\begin{tabular}{|c|c|c|c|c|c|c|c|c|c|}
\hline Variable & Mean & $\begin{array}{l}\text { Std. } \\
\text { dev. }\end{array}$ & Minimum & Maximum & $\begin{array}{l}\text { No. } \\
\text { cases }\end{array}$ & Missing & $\begin{array}{c}\text { Full } \\
\text { membership }\end{array}$ & $\begin{array}{l}\text { Crossover } \\
\text { point }\end{array}$ & $\begin{array}{l}\text { Full non- } \\
\text { membership }\end{array}$ \\
\hline Women on Boards & 14.68 & 6.75 & 3.5 & 28.6 & 27 & 0 & 30 & 20 & 10 \\
\hline Maternity Leave & 128.48 & 32.93 & 98 & 227 & 27 & 0 & 250 & 150 & 50 \\
\hline Paternity Leave & 10.48 & 17.15 & 0 & 90 & 27 & 0 & 15 & 9 & 3 \\
\hline Parental Leave & 435.44 & 415.08 & 0 & 1095 & 27 & 0 & 240 & 140 & 40 \\
\hline Form of Regulation & -- & -- & 0 & 1 & 27 & 0 & 0.90 & 0.55 & 0.20 \\
\hline Childcare Services & 16.03 & 13.34 & 1 & 59 & 27 & 0 & 33 & 20 & 10 \\
\hline $\begin{array}{l}\text { Female Part-time } \\
\text { Employment }\end{array}$ & 20.85 & 13.27 & 3 & 61 & 27 & 0 & 35 & 20 & 5 \\
\hline Female Labor Force & 64.74 & 7.62 & 43 & 77 & 27 & 0 & 65 & 45 & 25 \\
\hline Gender Equality & .73 & .04 & .6707 & .8453 & 27 & 0 & 1 & 0.5 & 0 \\
\hline
\end{tabular}

TABLE A3

Results of Calibration and Fuzzy Sets

\begin{tabular}{|c|c|c|c|c|c|c|c|c|c|}
\hline $\begin{array}{l}\text { EU } \\
\text { countries }\end{array}$ & $\begin{array}{l}\text { Set of EU } \\
\text { countries } \\
\text { with a } \\
\text { higher } \\
\text { number of } \\
\text { women on } \\
\text { boards }\end{array}$ & $\begin{array}{l}\text { Set of EU } \\
\text { countries } \\
\text { with high } \\
\text { level of } \\
\text { maternity } \\
\text { leave }\end{array}$ & $\begin{array}{c}\text { Set of EU } \\
\text { countries } \\
\text { with high } \\
\text { level of } \\
\text { paternity } \\
\text { leave }\end{array}$ & $\begin{array}{c}\text { Set of EU } \\
\text { countries } \\
\text { with high } \\
\text { level of } \\
\text { parental } \\
\text { leave }\end{array}$ & $\begin{array}{l}\text { Set of EU } \\
\text { countries } \\
\text { with high } \\
\text { level of } \\
\text { formal } \\
\text { childcare } \\
\text { services }\end{array}$ & $\begin{array}{l}\text { Set of EU } \\
\text { countries } \\
\text { with high } \\
\text { level of } \\
\text { gender } \\
\text { equality }\end{array}$ & $\begin{array}{l}\text { Set of EU } \\
\text { countries with } \\
\text { high level of } \\
\text { regulation for } \\
\text { female } \\
\text { representation } \\
\text { on board }\end{array}$ & $\begin{array}{c}\text { Set of EU } \\
\text { countries } \\
\text { with high } \\
\text { level of } \\
\text { female part- } \\
\text { time } \\
\text { employment }\end{array}$ & $\begin{array}{c}\text { Set of EU } \\
\text { countries } \\
\text { with high } \\
\text { level of } \\
\text { female } \\
\text { labor force }\end{array}$ \\
\hline & HighWOB & HighML & HighPL & HighPALp & HighFCHs & HighGE & HighREG & HighFpt & HighFlf \\
\hline AT & .08 & .24 & .01 & 1.00 & .02 & .81 & .39 & .93 & .91 \\
\hline $\mathrm{BE}$ & .11 & .21 & .05 & .77 & .83 & .84 & .98 & .92 & .81 \\
\hline BG & .07 & .91 & .95 & 1.00 & .03 & .81 & .01 & .03 & .83 \\
\hline CY & .02 & .33 & .01 & .01 & .43 & .74 & .01 & .20 & .88 \\
\hline $\mathrm{CZ}$ & .25 & .80 & .01 & 1.00 & 0.00 & .74 & .01 & .07 & .79 \\
\hline DE & .35 & .17 & .01 & 1.00 & .18 & .84 & .39 & .97 & .93 \\
\hline DK & .56 & .33 & .92 & .93 & 1.00 & .86 & .39 & .73 & .96 \\
\hline EE & .03 & .43 & .62 & 1.00 & .14 & .77 & .01 & .17 & .93 \\
\hline EL & .03 & .28 & .03 & .01 & .18 & .74 & .01 & .23 & .72 \\
\hline ES & .09 & .24 & .95 & .01 & .18 & .80 & .98 & .60 & .87 \\
\hline FI & .93 & .21 & .99 & .63 & .61 & .89 & .98 & .31 & .94 \\
\hline FR & .82 & .24 & .92 & 1.00 & .67 & .83 & .98 & .60 & .87 \\
\hline HU & .02 & .63 & .12 & 1.00 & .01 & .74 & .01 & .06 & .70 \\
\hline IE & .03 & .72 & .01 & .01 & .06 & .85 & .01 & .98 & .81 \\
\hline IT & .06 & .43 & .02 & 1.00 & .06 & .77 & .98 & .90 & .53 \\
\hline LT & .34 & .33 & 1.00 & .95 & .01 & .79 & .01 & .12 & .91 \\
\hline LU & .04 & .24 & .03 & 1.00 & .83 & .80 & .39 & .88 & .77 \\
\hline LV & .92 & .24 & .62 & 1.00 & .43 & .83 & .01 & .14 & .93 \\
\hline MT & .01 & .17 & .02 & .01 & 0 & .74 & .01 & .77 & .30 \\
\hline NL & .61 & .24 & .03 & .01 & .02 & .84 & .39 & 1.00 & .94 \\
\hline PL & .08 & .24 & .92 & 1.00 & .01 & .77 & .39 & .17 & .75 \\
\hline $\mathrm{PT}$ & .02 & .29 & .62 & .01 & .96 & .79 & .39 & .23 & .92 \\
\hline
\end{tabular}


TABLE A3

(Continued)

\begin{tabular}{|c|c|c|c|c|c|c|c|c|c|}
\hline $\begin{array}{l}\text { EU } \\
\text { countries }\end{array}$ & $\begin{array}{l}\text { Set of EU } \\
\text { countries } \\
\text { with a } \\
\text { higher } \\
\text { number of } \\
\text { women on } \\
\text { boards }\end{array}$ & $\begin{array}{c}\text { Set of EU } \\
\text { countries } \\
\text { with high } \\
\text { level of } \\
\text { maternity } \\
\text { leave }\end{array}$ & $\begin{array}{c}\text { Set of EU } \\
\text { countries } \\
\text { with high } \\
\text { level of } \\
\text { paternity } \\
\text { leave }\end{array}$ & $\begin{array}{c}\text { Set of EU } \\
\text { countries } \\
\text { with high } \\
\text { level of } \\
\text { parental } \\
\text { leave }\end{array}$ & $\begin{array}{l}\text { Set of EU } \\
\text { countries } \\
\text { with high } \\
\text { level of } \\
\text { formal } \\
\text { childcare } \\
\text { services }\end{array}$ & $\begin{array}{c}\text { Set of EU } \\
\text { countries } \\
\text { with high } \\
\text { level of } \\
\text { gender } \\
\text { equality }\end{array}$ & $\begin{array}{l}\text { Set of EU } \\
\text { countries with } \\
\text { high level of } \\
\text { regulation for } \\
\text { female } \\
\text { representation } \\
\text { on board }\end{array}$ & $\begin{array}{l}\text { Set of EU } \\
\text { countries } \\
\text { with high } \\
\text { level of } \\
\text { female part- } \\
\text { time } \\
\text { employment }\end{array}$ & $\begin{array}{c}\text { Set of EU } \\
\text { countries } \\
\text { with high } \\
\text { level of } \\
\text { female } \\
\text { labor force }\end{array}$ \\
\hline & HighWOB & HighML & HighPL & HighPALp & HighFCHs & HighGE & HighREG & HighFpt & HighFlf \\
\hline $\mathrm{RO}$ & .08 & & & & .01 & & & .17 & \\
\hline SE & .84 & .17 & .62 & & .97 & .87 & .39 & .4 & .96 \\
\hline SI & .40 & .21 & 1.00 & .97 & .98 & .81 & .01 & .14 & .88 \\
\hline SK & .13 & .17 & .01 & 1.00 & .01 & .75 & .01 & .06 & .79 \\
\hline UK & .41 & .72 & .92 & .01 & .01 & .81 & 30 & .98 & .91 \\
\hline
\end{tabular}

Outcome variable: HighWOB

TABLE A4

Analysis and Relevance of Necessity Conditions

Description

High Maternity Leave

Not High Maternity Leave

High Paternity Leave

Not High Paternity Leave

High Formal Childcare Services

Not High Formal Childcare Services

High Female Labor Force

Not High Female Labor Force

High Female Part Time Employment

Not High Female Part Time Employment

High Gender Equality

Not High Gender Equality

High Regulation

Not High Regulation

High Parental Leave

Not High Parental leave
Conditions tested Consistency Coverage Relevance Consistency Raw coverage

$\begin{array}{lrl}\text { HighML } & .50 & .39 \\ \sim \text { HighML } & .92 & .39 \\ \text { HighPL } & .72 & .46 \\ \sim \text { HighPL } & .41 & .20 \\ \text { HighFCHs } & .57 & .49 \\ \sim \text { HighFCHs } & .57 & .23 \\ \text { HighFlf } & 1.00 & .33 \\ \sim \text { HighFlf } & .26 & .39 \\ \text { HighFpt } & .61 & .35 \\ \sim \text { HighFpt } & .64 & .33 \\ \text { HighGE } & .98 & .33 \\ \sim \text { HighGE } & .38 & .51 \\ \text { HighREG } & .58 & .50 \\ \sim \text { HighREG } & .71 & .28 \\ \text { HighPALp } & .80 & .32 \\ \sim \text { HighPALp } & .25 & .21\end{array}$

.20

.39

conditions

Outcome variable: HighWOB 
FIGURE A1

Q14 XY PLOT - Distribution of Countries for Necessary Condition "High Level of Gender Equality"

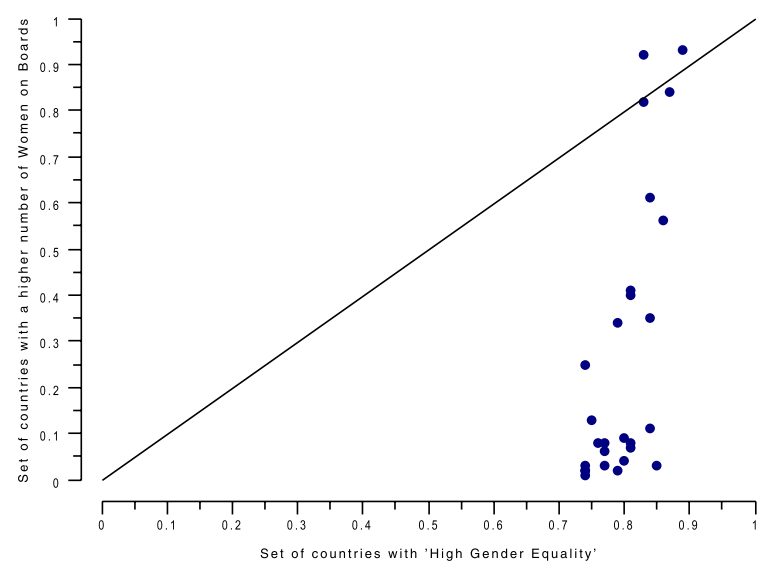

FIGURE A2

XY PLOT - Distribution of Countries for Necessary Condition "Not High Maternity Leave"

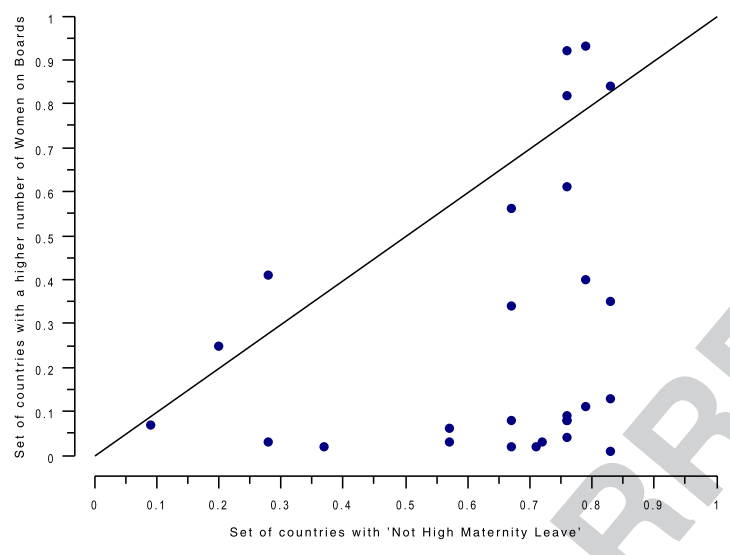

FIGURE A3

XY PLOT - Distribution of Countries for Necessary Condition "High Female Labor Force"

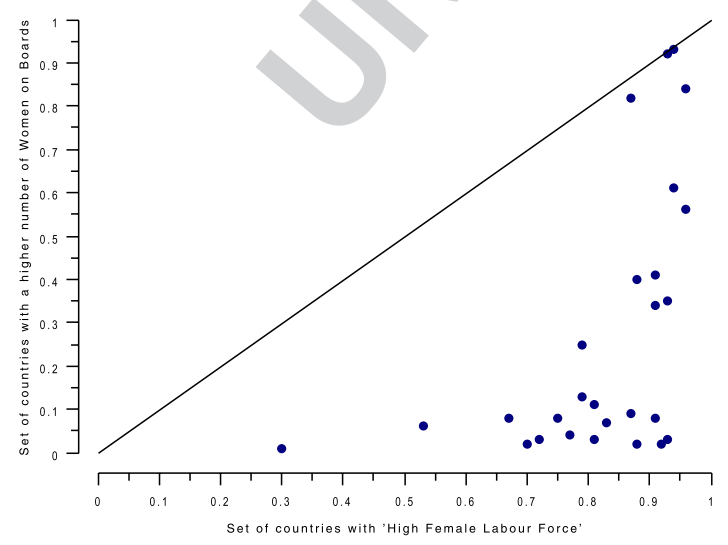

FIGURE A4

Distribution of Countries in the Fuzzy Set for "High Level of Maternity Leave"

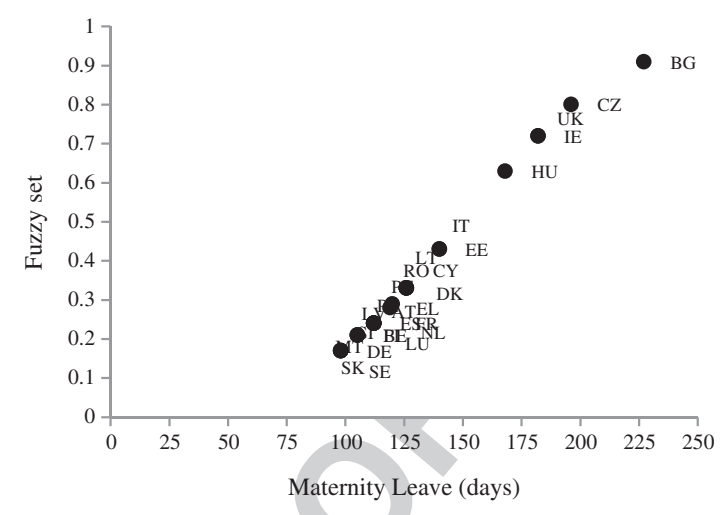

FIGURE A5

Distribution of Countries in the Fuzzy Set for "High Level of Paternity Leave"

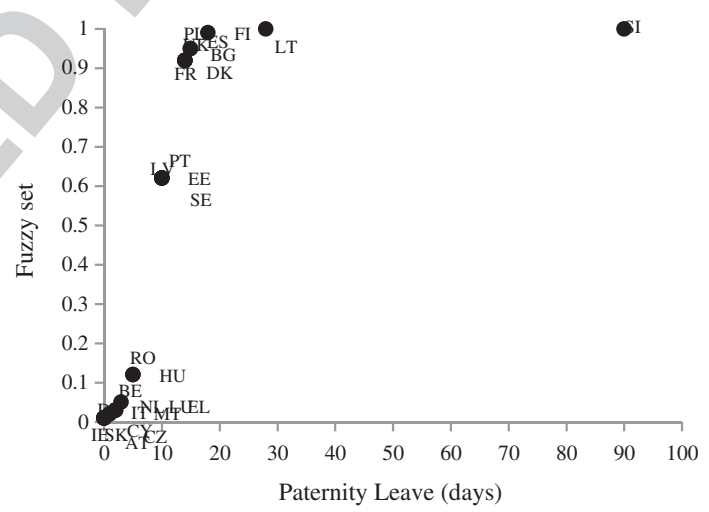

FIGURE A6

Distribution of Countries in the Fuzzy Set for "High Level of Parental Leave"

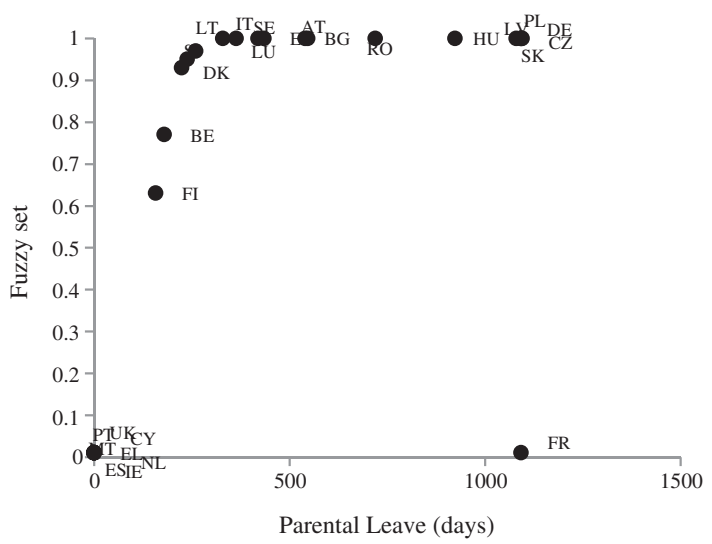


FIGURE A7

Distribution of Countries in the Fuzzy Set for "High Level of Formal Childcare Services"

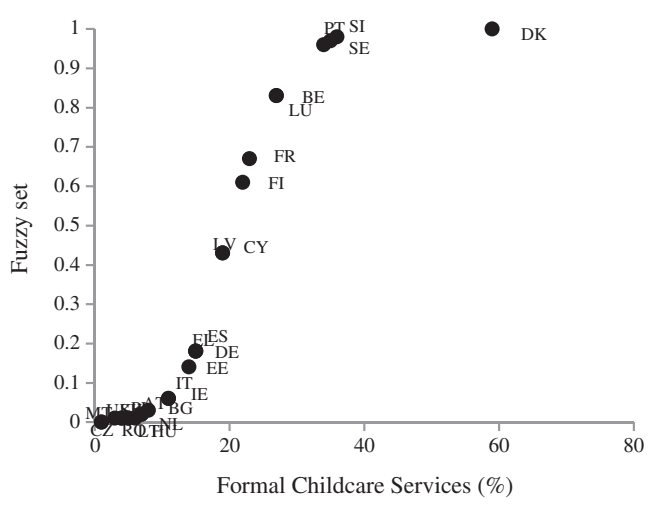

FIGURE A8

Distribution of Countries in the Fuzzy Set for "High Level of Gender Equality"

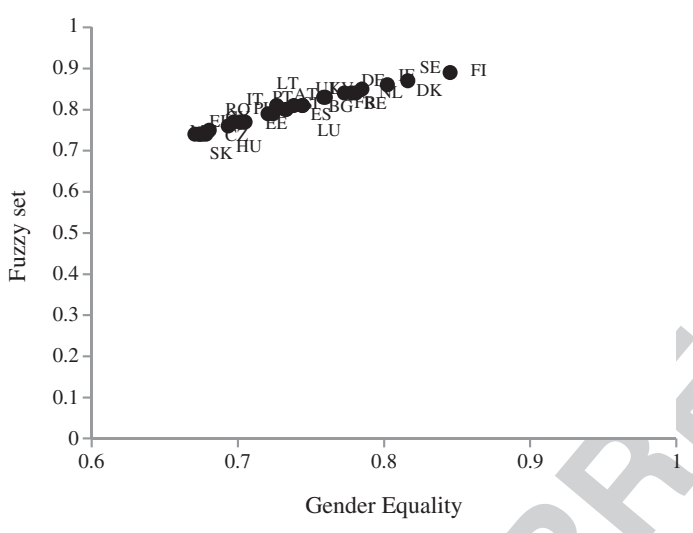

FIGURE A9

Distribution of Countries in the Fuzzy Set for "High Level of Regulation"

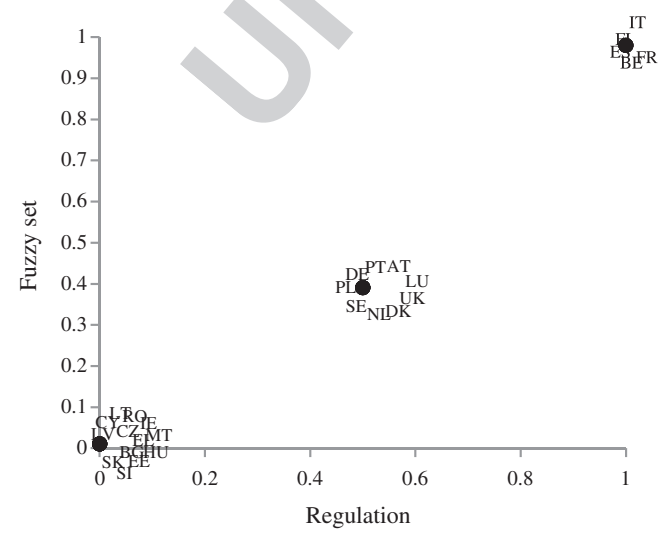

FIGURE A10

Distribution of Countries in the Fuzzy Set for "High Level of Female Part Time Employment"

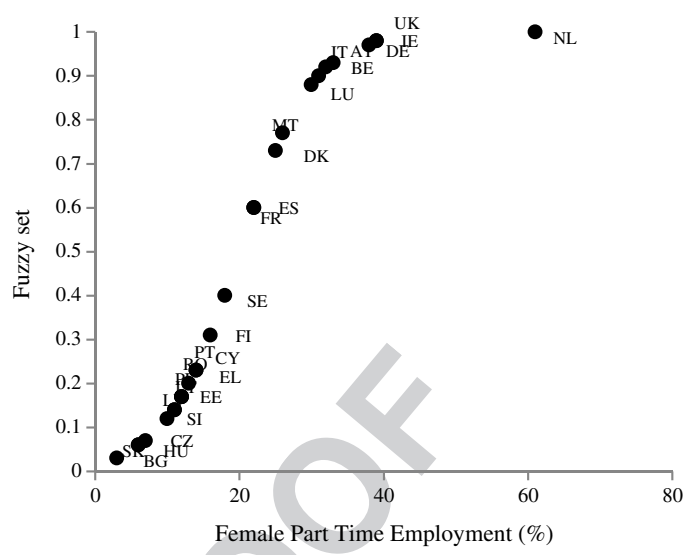

FIGURE A11

Distribution of Countries in the Fuzzy Set for "High Level of Female Labor Force"

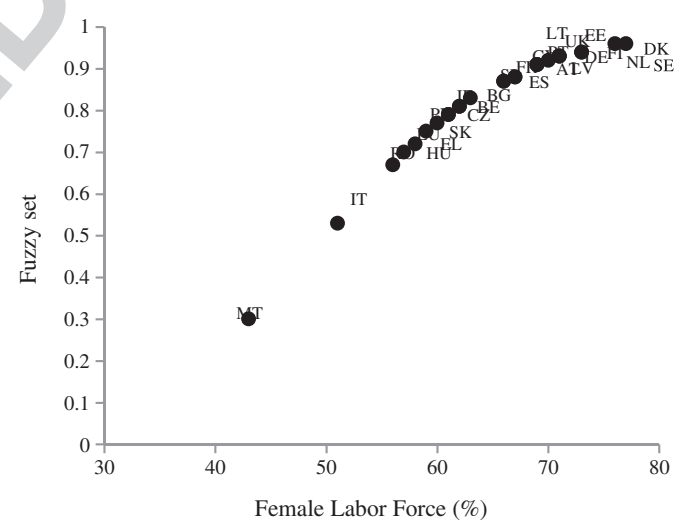

FIGURE A12

Distribution of Countries in the Fuzzy Set for "High Number of Women on Board"

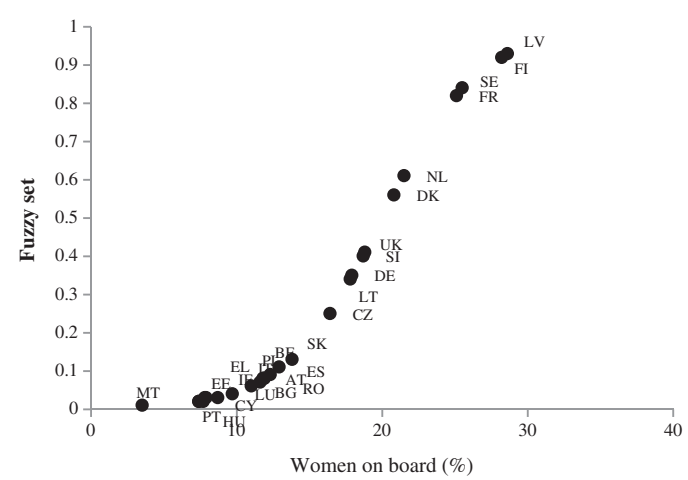




\section{REFERENCES}

Acker, J. 1992. Gendered institutions: From sex roles to gendered institutions, Contemporary Sociology, 21: 565-569.

Adams, R. B. \& Kirchmaier, T. 2013. Making it to the top: From female labor force participation to boardroom gender diversity. ECGI Finance Working Paper, 347/2013.

Adams, S. M. \& Flynn, P. M. 2005. Local knowledge advances women's access to corporate boards, Corporate Governance: An International Review, 13: 836-846.

Aguilera, R. V. \& Cuervo-Cazurra, A. 2004. Codes of good governance worldwide: What is the trigger?, Organization Studies, 25: 415-443.

Aguilera, R. V., Filatotchev, I., Gospel, H., \& Jackson, G. 2008. An organizational approach to comparative corporate governance: Costs, contingencies, and complementarities, Organization Science, 19: 475-492.

Aguilera, R. V. \& Jackson, G. 2003. The cross-national diversity of corporate governance: Dimensions and determinants, Academy of Management Review, 28: 447-465.

Ahern, K. R. \& Dittmar, A. K. 2012. The changing of the boards: The impact on firm valuation of mandated female board representation, Quarterly Journal of Economics, 127: 137-197.

Ahlering, B. \& Deakin, S. 2007. Labor regulation, corporate governance, and legal origin: A case of institutional complementarity?, Law E Society Review, 41: 865-908.

Alon, A. 2013. Complexity and dual institutionality: The case of IFRS adoption in Russia, Corporate Governance: An International Review, 21: 42-57.

Amable, B. 2000. Institutional complementarity and diversity of social systems of innovation and production, Review of International Political Economy, 7: 645-687.

Amable, B. 2003. The diversity of modern capitalism. Oxford: Oxford University Press.

Amable, B., Ernst, E., \& Palombarini, S. 2005. How do financial markets affect industrial relations: An institutional complementarity approach, Socio-Economic Review, 3: 311-330.

Aoki, M. 2001. Toward a comparative institutional analysis. Cambridge, MA: MIT Press.

Armstrong, J. \& Walby, S. 2012. Gender quotas in management boards. Brussels: European Parliament.

Aschcraft, K. L. 1999. Managing maternity leave: A qualitative analysis of temporary executive succession, Administrative Science Quarterly, 44: 240-280.

Bailey, K. 1994. Methods of social research, 4th edn. New York: Free Press.

Bergstø, K. 2013. Women mean business: Why and how Norway legislated gender balance on the boards of listed companies. In S. Machold, M. Huse, K. Hansen, \& M. Brogi (Eds.), Getting women on to corporate boards - A snowball starting in Norway. Cheltenham: Edward Elgar.

Brogi, M. 2013. Italy's lessons learnt from Norway. In S. Machold, M. Huse, K. Hansen, \& M. Brogi (Eds.), Getting women on to corporate boards - A snowball starting in Norway. Cheltenham: Edward Elgar.

Burri, S. \& Aune, H. 2013. Sex discrimination in relation to parttime and fixed-term work: The application of EU and national law in practice in 33 European countries. Brussels: European Union.

Campbell, J. L. 2011. The US financial crisis: Lessons for theories of institutional complementarity, Socio-Economic Review, 9: 211-234.

Connell, R. 1987. Gender and power: Society, the person, and sexual politics. Stanford, CA: Stanford University Press.

Council of Europe Family Policy Database. 2009. Reconciliation of work and family life. Available at: www.coe.int/familypolicy/database (accessed April 30, 2009).
Crouch, C. 2005. Complementarity and fit in the study of comparative capitalisms. In G. Morgan, R. Whitley, \& E. Moen (Eds.), Changing capitalisms? Internationalization, institutional change, and systems of economic organization: 167-189. Oxford: Oxford University Press.

De Anca, C. 2008. Women on corporate boards of directors in Spanish listed companies. In S. Vinnicombe, V. Singh, R. Burke, D. Bilimoria, \& M. Huse (Eds.), Women on corporate boards of directors: International research and practice: 96-107. Cheltenham: Edward Elgar.

Deeg, R. 2007. Complementarity and institutional change in capitalist systems, Journal of European Public Policy, 14: 611-630.

Denis, D. K. \& McConnell, J. J. 2003. International corporate governance, Journal of Financial and Quantitative Analysis, 38: $1-36$.

Denzau, A. T. \& North, D. C. 1994. Shared mental models: Ideologies and institutions, Kyklos, 47: 3-31.

Doldor, E., Vinnicombe, S., Gaughan, M., \& Sealy, R. 2012. Gender diversity on boards: The appointment process and the role of executive search firms. Equality and Human Rights Commission Research report 85.

Esping-Andersen, G. 1990. The three worlds of welfare capitalism. Cambridge: Polity.

Esping-Andersen, G. 1999. Social foundations of postindustrial economies. Oxford: Oxford University Press.

Eszter, S. 2013. Part-time work in Europe. Available at: https:/ / www. Q9 eurofound.europa.eu/publications / report/2011/working-conditions-law-and-regulation/part-time-work-in-europe (accessed August 11, 2013).

European Commission. 2012a. Women and men in decision-making. Available at: http://ec.europa.eu/justice/gender-equality/gender-decision-making/database/index_en.htm (accessed August 31, 2015).

European Commission. 2012b. Women in economic decision-making in the EU: Progress report. Luxembourg: Publications Office of the European Union.

European Commission. 2013. National factsheets: Gender balance on boards. Available at: http://ec.europa.eu/justice/gender-equality/files/womenonboards/womenonboards-factsheet.

European Commission. 2014. Database on women and men in decision-making: Methodology. Available at: http://ec.europa. eu/justice/gender-equality / files/database/wmid_methodology_ dec_2014.pdf (accessed August 31, 2015).

EU-SILC. 2012. Childcare arrangements. Available at: http://epp. eurostat.ec.europa.eu/cache/ITY_SDDS/DE/ilc_ca_esms.htm.

European Union. 2010. Directive 2010/18/EU Implementing the revised Framework Agreement on parental leave concluded by BUSINESSEUROPE, UEAPME, CEEP and ETUC and repealing Directive 96/34/EC. Official Journal of the European Union: L68/13-L68/20.

Ferreira, D. 2014. Board diversity: Should we trust research to inform policy?, Corporate Governance: An International Review, 23: 108-111.

Fiss, P. C. 2007. A set-theoretic approach to organizational configurations, Academy of Management Review, 32: 1180-1198.

Fiss, P. C. 2011. Building better causal theories: A fuzzy set approach to typologies in organization research, Academy of Management Journal, 54: 393-420.

Garcìa-Castro, R., Aguilera, V. R., \& Ariño, M. A. 2013. Bundles of firm corporate governance practices: A fuzzy set analysis, Corporate Governance: An International Review, 21:390-407.

Grandori, A. \& Furnari, S. 2008. A chemistry of organization: Combinatory analysis and design, Organization Studies, 29: 459-485.

Grosvold, J. 2011. Where are all the women? Institutional context and the prevalence of women on the corporate boards of directors, Business and Society, 50: 531-555. 
Grosvold, J. \& Brammer, S. 2011. National institutional systems as antecedents of female board representation: An empirical study, Corporate Governance: An International Review, 19: 116-135.

Höpner, M. 2005. What connects industrial relations and corporate governance? Explaining institutional complementarity, Socio-Economic Review, 3: 331-358.

Huse, M. \& Seierstad, C. 2014. Getting women on to corporate boards: Consequences of the Norwegian gender balance law, The European Financial Review, 37-39.

International Labor Organization. 2010. Maternity at work: A review of national legislation. Findings from the ILO Database of Conditions of Work and Employment Laws. Geneva: ILO. Available at: http://www.ilo.org/wcmsp5/groups/public/@dgreports / @dcomm/@publ/documents/publication/wcms_124442.pdf (accessed August 31, 2015).

Jackson, G. 2005. Toward a comparative perspective on corporate governance and labour management. RIETI Discussion Paper Series $04-\mathrm{E}-023$.

Jackson, G. \& Deeg, R. 2008. Comparing capitalisms: Understanding institutional diversity and its implications for international business, Journal of International Business Studies, 39: 540-561.

Judge, W. Q., Douglas, T. J., \& Kutan, A. M. 2008. Institutional antecedents of corporate governance legitimacy, Journal of Management, 34: 765-785.

Judge, W., Li, S., \& Pinsker, R. 2010. National adoption of international accounting standards: An institutional perspective, Corporate Governance: An International Review, 18: 161-174.

Kang, H., Chen, G., \& Gray, S. J. 2007. Corporate governance and board composition: Diversity and independence of Australian boards, Corporate Governance: An International Review, 15: 194-207.

Kang, N. \& Moon, J. 2012. Institutional complementarity between corporate governance and corporate social responsibility: A comparative institutional analysis of three capitalisms, Socio-Economic Review, 10: 85-108.

Kogut, B. \& Ragin, C. C. 2006. Exploring complexity when diversity is limited: Institutional complementarity in theories of rule of law and national systems revisited, European Management Review, 3: 44-59.

Lorber, J. 1994. Paradoxes of gender. New Haven, CT: Yale University Press.

Mandel, H. \& Semyonov, M. 2006. A welfare state paradox: State interventions and women's employment opportunities in 22 countries, American Journal of Sociology, 11: 1910-1949.

Mandel, H. \& Shalev, M. 2009. How welfare states shape the gender pay gap: A theoretical and comparative analysis, Social Forces, 87: 1873-1912.

Margherita, A., O’Dorchai, S., \& Bosch, J. 2009. Reconciliation between work, private and family life in the European Union. Luxembourg: Office for Official Publications of the European Communities. Available at: http://ec.europa.eu/eurostat/documents/3217494/5705547/KS-78-09-908-EN.PDF/6180b5e6-e4824d5f-a681-6a9bce05d733?version=1.0 (accessed August 31, 2015).

Martin, P. Y. 2004. Gender as social institution, Social Forces, 82: 1249-1273.

Mayer, K. U. 2009. Whose lives? How history, societies, and institutions define and shape life courses, Research in Human Development, 1: 161-187.

Milgrom, P. \& Roberts, J. 1995. Complementarities and fit strategy, structure and organizational change in manufacturing, Journal of Accounting and Economics, 19: 179-208.

Misra, J. \& Moller, S.. 2005. Familialism and welfare regimes: Poverty, employment, and family policies. Working Paper, 399, Luxembourg Income Study.

Q13 MISSOC. 2014. Comparative tables database. Available at: http:/ / www.missoc.org/MISSOC /INFORMATIONBASE/
COMPARATIVETABLES/MISSOCDATABASE/comparativeTableSearch.jsp (accessed August 31, 2015).

Moss, P. (Ed.) 2014. 10th International Review of Leave Policies and Q5 Related Research 2014. London: International Network on Leave Policies and Research. Available at: http://www.leavenetwork. org/fileadmin/Leavenetwork/Annual_reviews/2014_annual_ review_korr.pdf (accessed August 31, 2014).

Neale, W. C. 1988. Institutions. In M. Tools (Ed.), Foundations of institutional thought, vol. 1, : 227-256. New York: M.E. Sharpe.

Nelson, T. \& Levesque, L. L. 2007. The status of women in corporate governance in high-growth, high-potential firms, Entrepreneurship: Theory and Practice, 31: 209-232.

North, D. C. 1990. Institutions, institutional change, and economic performance. Oxford: Oxford University Press.

North, D. C. 1991. Institutions, Journal of Economic Perspectives, 5: 97-112.

Ntim, C. G. \& Soobaroyen, T. 2013. Corporate governance and performance in socially responsible corporations: New empirical insight from a neo-institutional framework, Corporate Governance: An International Review, 21: 468-494.

Nugent, J. B. \& Lin, J. Y. 1995. Institutions and economic development. In H. Chenery, T. N. Srinivasan, \& J. Behrman (Eds.), Handbook of development economics. Amsterdam: North-Holland.

OECD. 2012. Family database. Available at: www.oecd.org/social/ family/database (accessed August 31, 2015).

Orloff, A. S. 1993. Gender and the social rights of citizenship: The comparative analysis of gender relations and welfare states, American Sociological Review, 58: 303-328.

Orloff, A. S. 1996. Gender in the welfare state, Annual Review of Sociology, 22: 51-78.

Payne, G. \& Payne, J. 2004. Key concepts in social research. London: Sage Publications.

Ragin, C. C. 2000. Fuzzy-set social science. Chicago, IL: University of Chicago Press.

Ragin, C. C. 2002. Préface. In G. De Meur \& B. Rihoux (Eds.), L'Analyse qualiquantitative comparée (AQQC-QCA): Approche, techniques et applications en sciences humaines: 11-14. Louvainla-Neuve: Academia-Bruylant.

Ragin, C. C. 2006. Set relations in social research: Evaluating their consistency and courage, Political Analysis, 14: 291-310.

Ragin, C. C. 2008a. Re-designing social inquiry. Chicago, IL: University of Chicago Press.

Ragin, C. C. 2008b. User's guide to fuzzy-set/qualitative comparative analysis. Available at: http://www.u.arizona.edu/ cragin/ fsQCA/download/fsQCAManual.pdf (accessed August 31, 2015).

Ragin, C. C. 2009. Qualitative comparative analysis using fuzzy sets (fsQCA). In B. Rihoux \& C. C. Ragin (Eds.), Configurational comparative methods: Qualitative comparative analysis (QCA) and related techniques: 87-121. London: Sage Publications.

Ragin, C., Drass, K., \& Davey, S. 2006. Fuzzy-Set/Qualitative Comparative Analysis 2.0. Tucson, AZ: Department of Sociology, University of Arizona.

Ragin, C. C. \& Rihoux, B. 2004. Qualitative comparative analysis (QCA): State of the art and prospects, Qualitative Methods, 2: 3-13.

Rediker, K. \& Seth, A. 1995. Boards of directors and substitution effects of alternative governance mechanisms, Strategic Management Journal, 16: 85-99.

Rihoux, B. 2006. Qualitative comparative analysis (QCA) and related systematic comparative methods: Recent advances and remaining challenges for social science research, International Sociology, 21: 679-706.

Schneider, C. Q. \& Wagemann, C. 2012. Set-theoretic methods for the social sciences: A guide to qualitative comparative analysis. Cambridge: Cambridge University Press.

Scott, J. 1990. A matter of record: Documentary sources in social research. Cambridge: Polity. 
Scott, W. R. 1987. The adolescence of institutional theory, Administrative Science Quarterly, 32: 493-511.

Seierstad, C., Warner-Søderholm, G., Torchia, M., \& Huse, M. 2015. Increasing the number of women on boards: The role of actors and processes, Journal of Business Ethics. DOI:10.1007/s10551015-2715-0.

Singh, V. \& Vinnicombe, S. 2004. Why so few women directors in top UK boardrooms? Evidence and theoretical explanations, Corporate Governance: An International Review, 12: 479-488.

Teigen, M. 2012. Gender quotas on corporate boards: On the diffusion of a distinct national policy reform. In F. Engelstad \& M. Teigen (Eds.), Firms, boards and gender quotas: Comparative perspectives: 115-146. Bingley: Emerald Group Publishing.

Terjesen, S., Aguilera, R. V., \& Lorenz, R. 2014. Legislating a woman's seat on the board: Institutional factors driving gender quotas for boards of directors, Journal of Business Ethics, 50: 177-186.

Terjesen, S., Sealy, R., \& Singh, V. 2009. Women directors on corporate boards: A review and research agenda, Corporate Governance: An International Review, 17: 320-327.

Terjesen, S. \& Singh, V. 2008. Female presence on corporate boards: A multi-country study of environmental context, Journal of Business Ethics, 83: 55-63.

Thomsen, H. \& Urth, H. 2010. Costs and benefits of maternity and paternity leave. Brussels: European Parliament.

Toomey, C. 2008. Quotas for women on the board: Do they work? The Sunday Times, June 8.

Weimer, J. \& Pape, J. C. 1999. A taxonomy of systems of corporate governance, Corporate Governance: An International Review, 7: $152-166$.

Williams, J. 2000. Unbending gender: Why work and family conflict and what to do about it. New York: Oxford University Press.

Williams, J. C. 2005. The glass ceiling and the maternal wall in academia, New Directions for Higher Education, 2005: 91-105.

World Economic Forum. 2013. The Global Gender Gap Report. Geneva: World Economic Forum.

Zattoni, A. \& Cuomo, F. 2008. Why adopt codes of good governance? A comparison of institutional and efficiency perspectives, Corporate Governance: An International Review, 16: 1-15.

Zattoni, A., Pedersen, T., \& Kumar, V. 2009. The performance of group-affiliated firms during institutional transitions: A longitudinal study of Indian firms, Corporate Governance: An International Review, 17: 510-523.
Michela Iannotta is a $\mathrm{PhD}$ candidate in Management at Sapienza University of Rome, Italy. She has published several articles in the area of human resource management and diversity management. Her main research interests include institutional theory and its application in organizational studies, configurational theory, complementarities-based approaches and research methods in organizational research.

Mauro Gatti is Full Professor of Business Organization and Human Resource Management in the Department of Management at Sapienza University of Rome, Italy. He published several articles and monographs on corporate governance, human resource practices and value creation, with particular focus on diversity management and corporate welfare. His main research interests include firm governance and institutional theory, work organization, corporate welfare, training and corporate universities.

Morten Huse is Professor of Organization and Management at BI Norwegian Business School and holds a Chair of Unternehmensführung, Wirtschaftsethik und gesellschaftlichen Wandel at the University of Witten/ Herdecke. Most of his recent work concerns value-creating boards and women on boards, and he has published widely on these topics. Between 2008 and 2014 he was member of Catalyst Europe Advisory Board and between 2010 and 2012 President of the European Academy of Management. In 2013 he won an awarded from TIAW (The International Alliance of Women) for Championing the Economic Empowerment of Women. For 2014 he was awarded a research grant at Sapienza University. He is board chair of Göttingen University Diversity Institute. 


\section{Author Query Form}

\section{Journal: Corporate Governance: An International Review}

\section{Article: corg_12140}

Dear Author,

During the copyediting of your paper, the following queries arose. Please respond to these by annotating your proofs with the necessary changes/additions.

- If you intend to annotate your proof electronically, please refer to the E-annotation guidelines.

- If you intend to annotate your proof by means of hard-copy mark-up, please use the standard proofing marks. If manually writing corrections on your proof and returning it by fax, do not write too close to the edge of the paper. Please remember that illegible mark-ups may delay publication.

Whether you opt for hard-copy or electronic annotation of your proofs, we recommend that you provide additional clarification of answers to queries by entering your answers on the query sheet, in addition to the text mark-up.

\begin{tabular}{|c|c|c|}
\hline Query No. & Query & Remark \\
\hline Q1 & AUTHOR: Please provide telephone and fax contact details. & \\
\hline Q2 & $\begin{array}{l}\text { AUTHOR: Please confirm that given names (red) and surnames/family names (green) have been } \\
\text { identified correctly. }\end{array}$ & \\
\hline Q3 & $\begin{array}{l}\text { AUTHOR: International Network on Leave Policies and Research has been changed to Moss (as he } \\
\text { is editor). However, International Network on Leave Policies and Research was not cited in the text. } \\
\text { Please add Moss (2014) to text or delete. }\end{array}$ & \\
\hline Q4 & $\begin{array}{l}\text { AUTHOR: The citation "2012" (original) has been changed to "European Commission, 2012a, } \\
2012 b \text { ". Please check if appropriate. }\end{array}$ & \\
\hline Q5 & $\begin{array}{l}\text { AUTHOR: Reference "Moss (2014)" is not cited in the text. Please indicate where it should be } \\
\text { cited; or delete from the reference list. }\end{array}$ & \\
\hline Q6 & $\begin{array}{l}\text { AUTHOR: "European Commission, } 2010 \text { " is not given in the reference list. Please provide details } \\
\text { in the list or delete the citation from the text. }\end{array}$ & \\
\hline Q7 & $\begin{array}{l}\text { AUTHOR: The citation "Ragin, 2008, 2009" (original) has been changed to "Ragin, 2008a, 2008b, } \\
\text { 2009". Please check if appropriate. }\end{array}$ & \\
\hline Q8 & $\begin{array}{l}\text { AUTHOR: Reference "International Labor Organization (2010)" is not cited in the text. Please } \\
\text { indicate where it should be cited; or delete from the reference list. }\end{array}$ & \\
\hline Q9 & $\begin{array}{l}\text { AUTHOR: Reference "Eszter (2013)" is not cited in the text. Please indicate where it should be } \\
\text { cited; or delete from the reference list. }\end{array}$ & \\
\hline Q10 & $\begin{array}{l}\text { AUTHOR: Eurofound } 2007 \text { changed to Eszter } 2013 \text {. However, Eurofound } 2007 \text { was not cited in the } \\
\text { text. Please cite Eszter } 2013 \text { in text or delete. }\end{array}$ & \\
\hline Q11 & AUTHOR: Please provide accessed date for reference European Commission. 2013. & \\
\hline Q12 & AUTHOR: Please check URL and provide accessed date for reference EU-SILC. 2012. & \\
\hline Q13 & $\begin{array}{l}\text { AUTHOR: Reference "MISSOC (2014)" is not cited in the text. Please indicate where it should be } \\
\text { cited; or delete from the reference list. }\end{array}$ & \\
\hline Q14 & AUTHOR: Please check if figures A1, A2 and A3 were captured correctly. & \\
\hline
\end{tabular}


Required software to e-Annotate PDFs: Adobe Acrobat Professional or Adobe Reader (version 7.0 or above). (Note that this document uses screenshots from Adobe Reader $\mathrm{X}$ )

The latest version of Acrobat Reader can be downloaded for free at: http://get.adobe.com/uk/reader/

Once you have Acrobat Reader open on your computer, click on the Comment tab at the right of the toolbar:

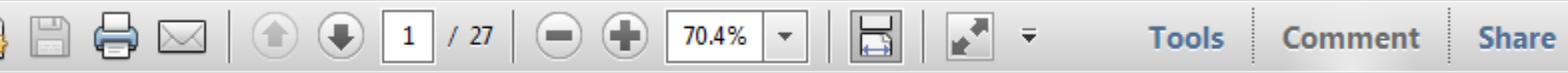

This will open up a panel down the right side of the document. The majority of tools you will use for annotating your proof will be in the Annotations section, pictured opposite. We've picked out some of these tools below:

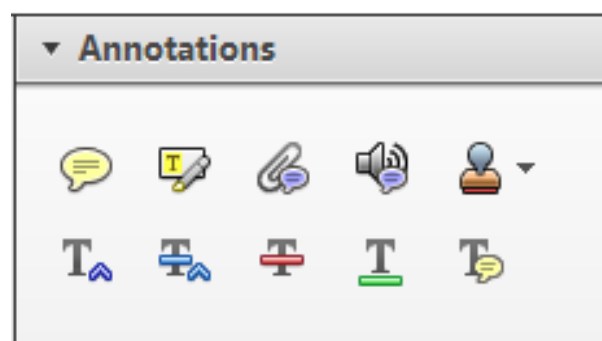

1. Replace (Ins) Tool - for replacing text.

Strikes a line through text and opens up a text box where replacement text can be entered.

How to use it

- Highlight a word or sentence.

- Click on the Replace (Ins) icon in the Annotations section.

- Type the replacement text into the blue box that appears.

Idard tramework for the analysis of $\mathrm{m}$ icy-Nevertheless, it also led to exog،

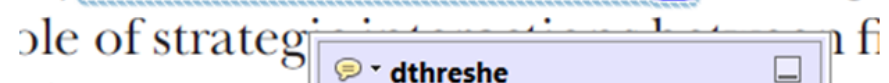
aber of comp 08/06/2011 15:58:17 is that the s1 nain compo: be level, are exc nc

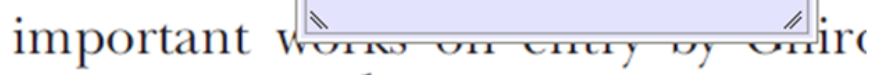
M heneferth) ${ }^{1}$ we anen the "hlarl $\mathrm{l}$

3. Add note to text Tool - for highlighting a section to be changed to bold or italic.

T Highlights text in yellow and opens up a text box where comments can be entered.

\section{How to use it}

- Highlight the relevant section of text.

- Click on the Add note to text icon in the Annotations section.

- Type instruction on what should be changed regarding the text into the yellow box that appears.

namic responses of mark ups ent with the VAR evidence

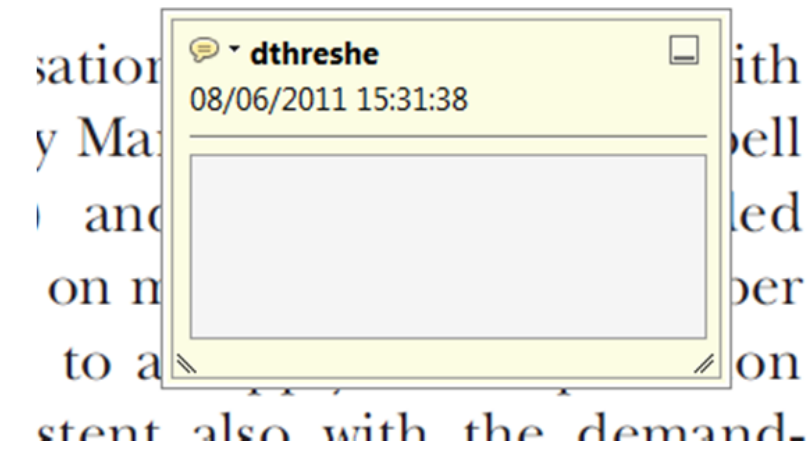

2. Strikethrough (Del) Tool - for deleting text.

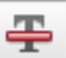

Strikes a red line through text that is to be deleted.

How to use it

- Highlight a word or sentence.

- Click on the Strikethrough (Del) icon in the Annotations section.

there is no room tor extra prohts al c ups are zero and the number of ret) values are not determined by Blanchard and Kiyotaki (1987), sfect competition in general equilil ts of aggregate demand and supply lassical framework assuming monol eph on evorenous number of firme

4. Add sticky note Tool - for making notes at specific points in the text.

Marks a point in the proof where a comment needs to be highlighted.

How to use it

- Click on the Add sticky note icon in the Annotations section.

- Click at the point in the proof where the comment should be inserted.

- Type the comment into the yellow box that appears.

iaisu airu suppiy sirucks. hivsl ui

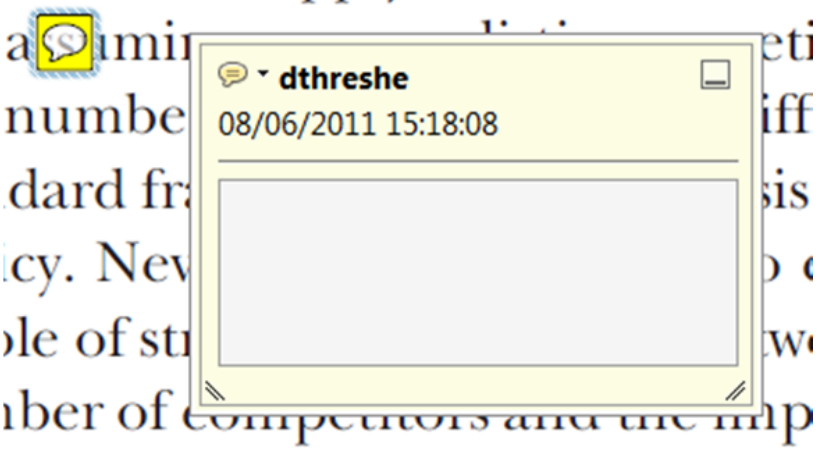

is that the structure of the secto. 
5. Attach File Tool - for inserting large amounts of text or replacement figures.

Inserts an icon linking to the attached file in the appropriate pace in the text.

How to use it

- Click on the Attach File icon in the Annotations section.

- Click on the proof to where you'd like the attached file to be linked.

- Select the file to be attached from your computer or network.

- Select the colour and type of icon that will appear in the proof. Click OK.

E N D

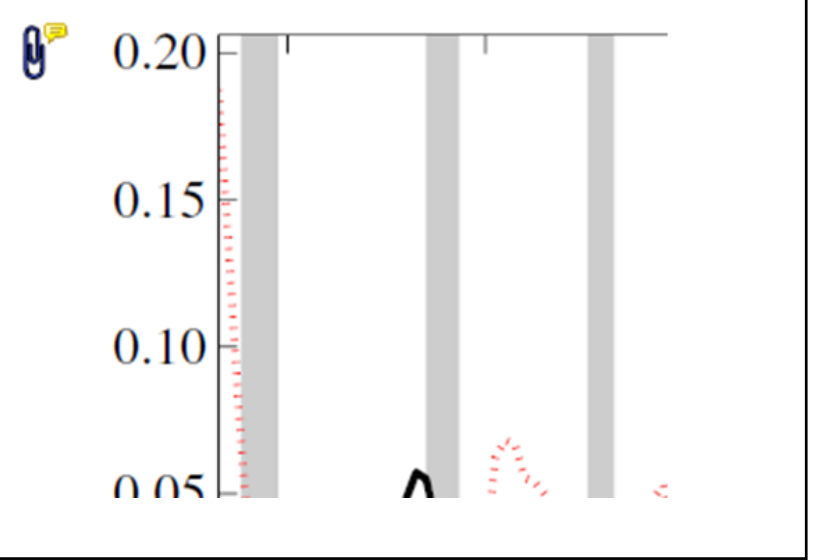

6. Add stamp Tool - for approving a proof if no corrections are required.

- Inserts a selected stamp onto an appropriate place in the proof.

\section{How to use it}

- Click on the Add stamp icon in the Annotations section.

- $\quad$ Select the stamp you want to use. (The Approved stamp is usually available directly in the menu that appears).

- Click on the proof where you'd like the stamp to appear. (Where a proof is to be approved as it is, this would normally be on the first page).

or the business cycie, starting with the on perfect competition, constant ret

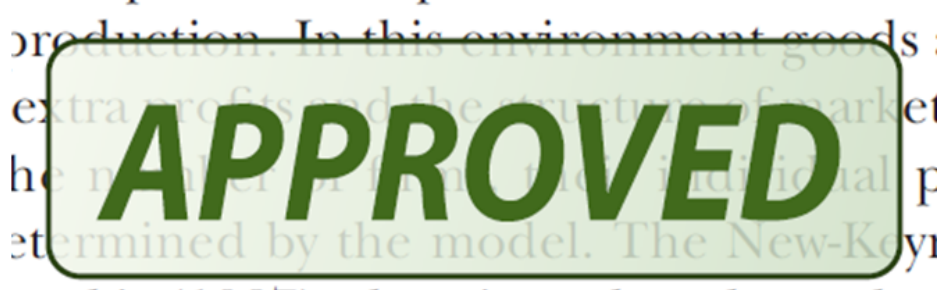
otaki (1987), has introduced produc general equilibrium models with nomin:

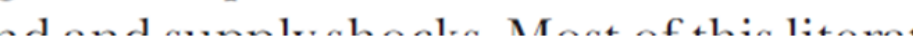

- Drawing Markups

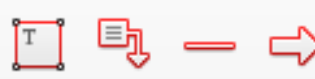

$0 \bigcirc \sqrt{6} \otimes$

\section{How to use it}

- Click on one of the shapes in the Drawing Markups section.

- Click on the proof at the relevant point and draw the selected shape with the cursor.

- To add a comment to the drawn shape, move the cursor over the shape until an arrowhead appears.

- Double click on the shape and type any text in the red box that appears.
7. Drawing Markups Tools - for drawing shapes, lines and freeform annotations on proofs and commenting on these marks.

Allows shapes, lines and freeform annotations to be drawn on proofs and for comment to be made on these marks.

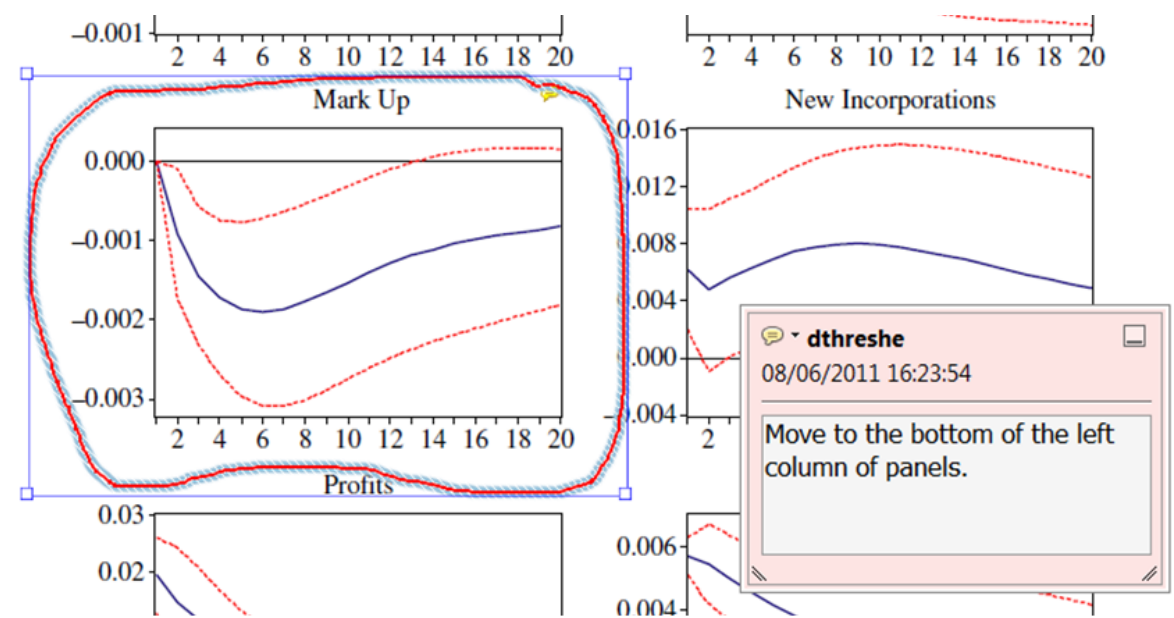

For further information on how to annotate proofs, click on the Help menu to reveal a list of further options:

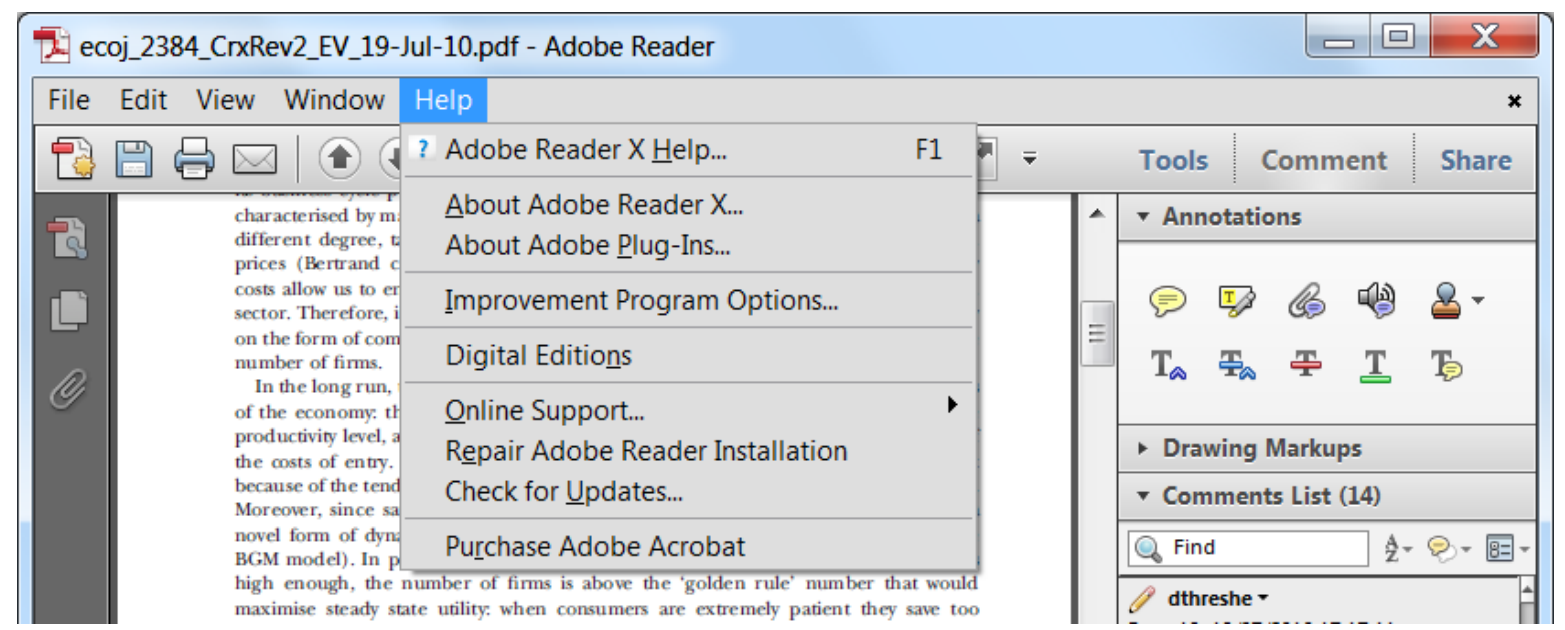

